Article

\title{
Attempts to Access a Series of Pyrazoles Lead to New Hydrazones with Antifungal Potential against Candida Species including Azole-Resistant Strains
}

\author{
Georgiana Negru $^{1}$, Laure Kamus ${ }^{2}$, Elena Bîcu ${ }^{1, *}$, Sergiu Shova ${ }^{3}$ (D), Boualem Sendid ${ }^{2}$ (D), Faustine Dubar ${ }^{2, *(D)}$ \\ and Alina Ghinet $1,4,5, *$ (D)
}

1 Faculty of Chemistry, “Alexandru Ioan Cuza” University of Iași, Bd. Carol I 11, 700506 Iași, Romania; georgiana_16_95@yahoo.com

2 Inserm U1285, CHU Lille, UGSF UMR CNRS 8576, Glycobiology in Fungal and Clinical Applications, Unité de Glycobiologie Structurale et Fonctionnelle, University of Lille, 59000 Lille, France; laurekamus@aol.com (L.K.); boualem.sendid@univ-lille.fr (B.S.)

3 "Petru Poni" Institute of Macromolecular Chemistry, 700487 Iași, Romania; shova@icmpp.ro

4 Laboratory of Sustainable Chemistry and Health, Health and Environment Department, Junia, 59000 Lille, France

5 Inserm, CHU Lille, Institut Pasteur Lille, U1167-RID-AGE_Facteurs de Risque et Déterminants

Moléculaires des Maladies Liées au Vieillissement, University of Lille, 59000 Lille, France

* Correspondence: elena@uaic.ro (E.B.); faustine.dubar@univ-lille.fr (F.D.); alina.ghinet@junia.com (A.G.)

check for

updates

Citation: Negru, G.; Kamus, L.; Bîcu,

E.; Shova, S.; Sendid, B.; Dubar, F.;

Ghinet, A. Attempts to Access a

Series of Pyrazoles Lead to New

Hydrazones with Antifungal

Potential against Candida Species

including Azole-Resistant Strains.

Molecules 2021, 26, 5861. https://

doi.org/10.3390/molecules26195861

Academic Editor: Francesca Mancianti

Received: 19 August 2021

Accepted: 24 September 2021

Published: 27 September 2021

Publisher's Note: MDPI stays neutral with regard to jurisdictional claims in published maps and institutional affiliations.

Copyright: (c) 2021 by the authors. Licensee MDPI, Basel, Switzerland. This article is an open access article distributed under the terms and conditions of the Creative Commons Attribution (CC BY) license (https:/ / creativecommons.org/licenses/by/ $4.0 /)$.

\begin{abstract}
The treatment of benzylidenemalononitriles with phenylhydrazines in refluxing ethanol did not provide pyrazole derivatives, but instead furnished hydrazones. The structure of hydrazones was secured by X-ray analysis. The chemical proof was also obtained by direct reaction of 3,4,5trimethoxybenzaldehyde with 2,4-dichlorophenylhydrazine. Newly synthesized hydrazones were tested against eight Candida spp. strains in a dose response assay to determine the minimum inhibitory concentration ( $\mathrm{MIC}_{99}$ ). Five compounds were identified as promising antifungal agents against Candida spp. (C. albicans SC5314, C. glabrata, C. tropicalis, C. parapsilosis and C. glabrata (R azoles)), with $\mathrm{MIC}_{99}$ values ranging from 16 to $32 \mu \mathrm{g} / \mathrm{mL}$ and selective antifungal activity over cytotoxicity.
\end{abstract}

Keywords: hydrazone; Candida species; antifungal agents; Candida albicans; Candida glabrata

\section{Introduction}

Antifungal therapies evolved slowly during the early years of the twentieth century, with the development of antifungal agents lagging that of antibacterial agents. The current therapeutic arsenal for the systemic treatment of antifungal infections mainly includes polyenes, azoles, echinocandins and pyrimidine classes of compounds.

In 2020, the World Health Organization (WHO) set up the "WHO antifungal expert group on identifying priority fungal pathogens" posing a high risk to human health [1]. The azole-resistant fungal pathogens Candida spp. were identified as preoccupying pathogens of global public health importance. The main Candida species resistant to azoles drugs is Candida krusei (intrinsic resistance), while those with an acquired resistance are certain strains of Candida glabrata and rare strains of Candida tropicalis, Candida parapsilosis and Candida kefyr. The lack of therapeutic innovations or new chemical families under development for the discovery of therapeutic alternatives has reached a critical level.

Identifying new experimental drugs is challenging and expected more than ever. There are only a few different classes from a mechanistic point of view that are currently used to treat serious fungal infections.

The treatment of invasive candidiasis, which represent the most serious clinical forms in hospitals, is the subject of several international recommendations, in particular those published by the Infectious Diseases Society of America (IDSA) [2] and the European Society 
of Clinical Microbiology and Infectious Diseases (ESCMID) [3-5], with some adaptations dependent on involved Candida species and hospital wards (resuscitation, oncohematology, neonatology, etc.).

Currently, treatment is based on the use of fluconazole, if the patient is in stable condition, or on the use of echinocandins, if the patient is in a severe state. Fluconazole and caspofungin are consequently the most used drugs in clinics today for the treatment of Candida infections. Fluconazole, a fungistatic from the azole family, diminishes the conversion of lanosterol to ergosterol, which affects fungal membrane functions and inhibits cell multiplication. Caspofungin, from the family of echinocandins, has fungicidal activity against Candida spp. through inhibition of the synthesis of $\beta-(1,3)$-D-glucan, a major constituent of the fungal cell wall [6].

In case of intolerance to these molecules or resistance demonstrated by antifungal susceptibility testing (AST), liposomal amphotericin B is considered as a good alternative choice.

The main limitations of the use of these molecules are related to: (i) the pharmacokinetic features of each molecule; (ii) susceptibility to antifungals of the Candida species involved in tissue infection; (iii) the clinical background of the treated patient (neutropenic or not, neonatology, solid organ transplant, etc.).

Hydrazone derivatives and especially acylhydrazones have been described as antifungal agents on Candida spp. Acylhydrazone A (Figure 1) displayed antifungal potential on C. glabrata [7]. Acylbarbituric acid hydrazone B inhibited the growth of C. albicans and C. glabrata with $\mathrm{MIC}_{80}$ values of $62 \mu \mathrm{g} / \mathrm{mL}$ and $31 \mu \mathrm{g} / \mathrm{mL}$, respectively (Figure 1) [8]. Hydrazone $\mathbf{C}$ was assayed for broad-spectrum antifungal activity against clinical isolates of Candida spp. and showed bioactivity against C. albicans, C. glabrata and C. tropicalis, with MIC values ranging from 4 to $128 \mu \mathrm{g} / \mathrm{mL}$ (Figure 1) [9]. Moderate antifungal potency was also registered for hydrazone $\mathbf{D}$, bearing electro-withdrawing substituents on C. glabrata and C. tropicalis (Figure 1) [10]. In this report, a new series of hydrazones was synthesized and identified as effective on Candida spp., including azole- or echinocandin-resistant strains (compounds 1a-o, Figure 1).

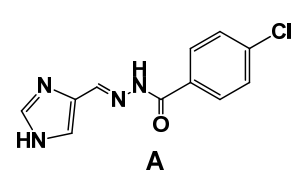

C. glabrata: $\mathrm{MIC}_{50}=15.7 \mu \mathrm{M}$

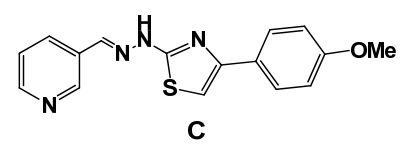

C. albicans (8 strains): MIC $=4-32 \mu \mathrm{g} / \mathrm{mL}$ C. glabrata (4 strains): $\mathrm{MIC}=16-64 \mu \mathrm{\mu g} / \mathrm{mL}$ C. glabrata (4 strains): $\mathrm{MIC}=16-64 \mu \mathrm{g} / \mathrm{mL}$
C. tropicalis (3 strains): $\mathrm{MIC}=64-128 \mu \mathrm{g} / \mathrm{mL}$

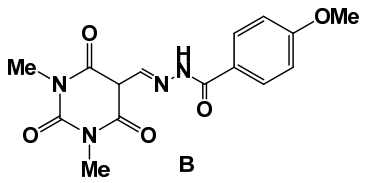

C. albicans: $\mathrm{MIC}_{80}=62 \mu \mathrm{g} / \mathrm{mL}$ C. glabrata: $\mathrm{MIC}_{80}=31 \mu \mathrm{g} / \mathrm{mL}$

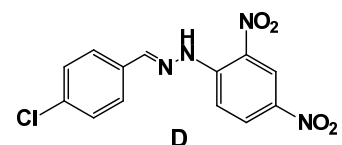

C. glabrata: $26 \%$ inh at $400 \mu \mathrm{g} / \mathrm{mL}$ C. tropicalis: $52 \%$ inh at $400 \mu \mathrm{g} / \mathrm{mL}$

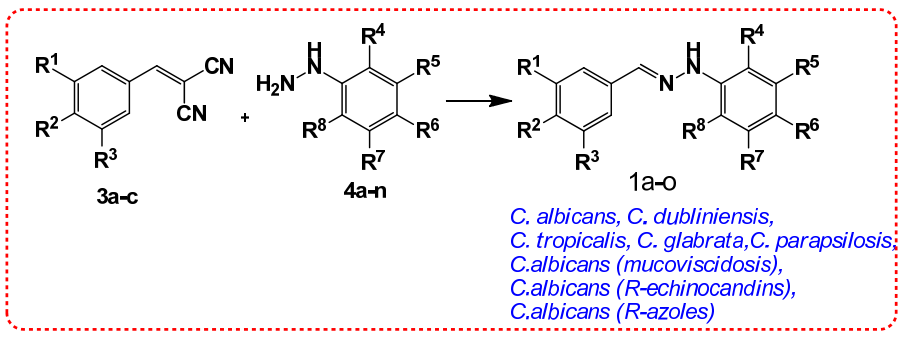

Figure 1. Structure of a selection of anti-Candida experimental drugs (A-D) and of target hydrazones 1a-o. 


\section{Results and Discussion}

In the frame of an ongoing medicinal chemistry program, an attempt to access new pyrazole derivatives of general structures $\mathbf{5}$ and $\mathbf{6}$, starting from benzylidenemalononitriles $3 \mathbf{a}-\mathbf{c}$, has been tried. The latter have been easily obtained by the Knoevenagel reaction of aldehydes $\mathbf{2 a}-\mathbf{c}$ with malononitrile in the presence of piperidine in refluxing ethanol (Schemes 1 and 2). They were next reacted with substituted phenylhydrazines $\mathbf{4 a}-\mathbf{n}$ in ethanol at reflux. The expected pyrazolines $\mathbf{5 a - 0}$ and/or $\mathbf{6 a}-\mathbf{0}$ could not be obtained. The same operatory conditions were previously described to afford aminopyrazole derivatives $[11,12]$. However, in our case, no trace of the target heterocycle was detected in the crude by ${ }^{1} \mathrm{H}-\mathrm{NMR}$ and TLC monitoring. Instead, in all cases, a different product was detected and isolated. The structure of the final product was resolved as a hydrazone derivative and secured by performing an X-ray on compounds $1 \mathbf{e}$ and $\mathbf{1 i}$ of the series (Figure 2). In addition, a chemical proof was also obtained by reacting aldehyde $\mathbf{2 a}$ with hydrazine $4 \mathbf{e}$, which provided the same hydrazone 1e. This confirmed the loss of the malononitrile unit during the reaction of benzylidenemalononitriles 3a-c with phenylhydrazines $\mathbf{4 a - n}$, explaining undoubtedly the formation of hydrazones 1a-o (Scheme 3).

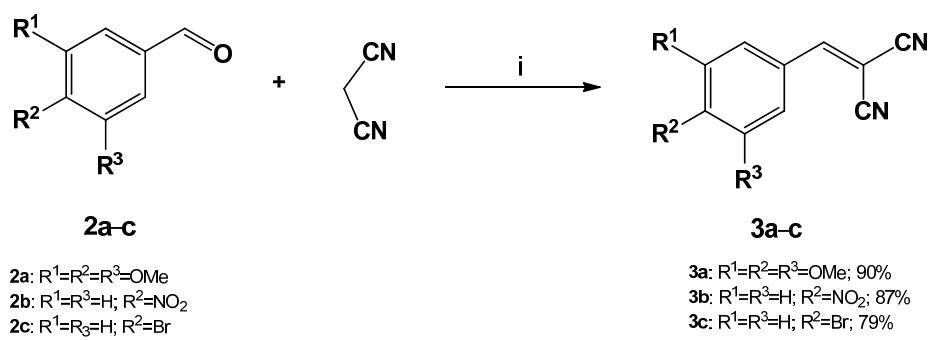

Scheme 1. Reagents and conditions: (i) piperidine, EtOH, reflux, 6-8 h.
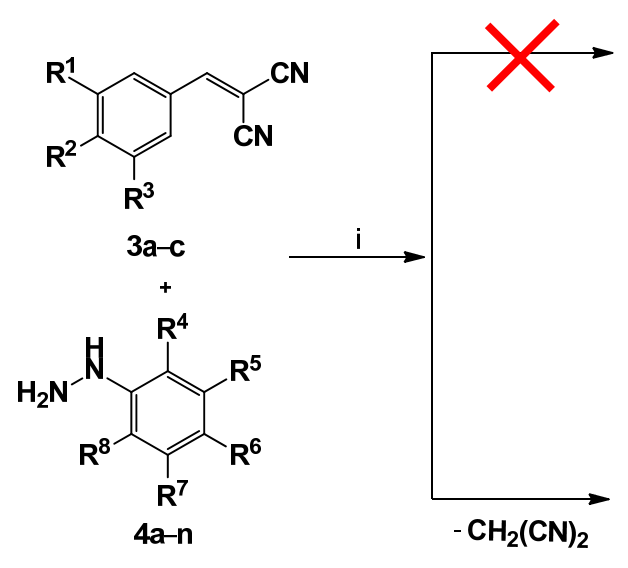<smiles>[R]c1cc(C2NN(c3c([R])c([R])c([R])c([R])c3[R])C(N)=C2C)c([R])c([R])c1[R]</smiles><smiles>[R]c1cc(/C=C2\C(=N)N(c3c([R])c([R])c([R])c([R])c3[R])N=C2N)cc([R])c1[R]</smiles>

1a: $R^{1}=R^{2}=R^{3}=O M e, R^{4}=C F_{3}, R^{5}=R^{6}=R^{7}=R^{8}=H$ 1b: $R^{1}=R^{2}=R^{3}=O M e, R^{4}=O M e, R^{5}=R^{6}=R^{7}=R^{8}=H$ 1c: $R^{1}=R^{2}=R^{3}=O M e, R^{4}=B r, R^{5}=R^{6}=R^{7}=R^{8}=H$ 1d: $R^{1}=R^{2}=R^{3}=O M e, R^{4}=C l, R^{5}=R^{6}=R^{7}=R^{8}=H$ 1e: $R^{1}=R^{2}=R^{3}=O M e, R^{4}=R^{6}=C l, R^{5}=R^{7}=R^{8}=H$ 1f: $R^{1}=R^{2}=R^{3}=O M e, R^{4}=R^{6}=F, R^{5}=R^{7}=R^{8}=H$ 1g: $R^{1}=R^{2}=R^{3}=O M e, R^{4}=M e, R^{5}=R^{6}=R^{7}=R^{8}=H$ 1h: $R^{1}=R^{2}=R^{3}=O M e, R^{6}=C l, R^{4}=R^{5}=R^{7}=R^{8}=H$ 1i: $R^{1}=R^{2}=R^{3}=O M e, R^{4}=F, R^{5}=R^{6}=R^{7}=R^{8}=H$ 1j: $R^{1}=R^{2}=R^{3}=O M e, R^{4}=R^{5}=R^{6}=R^{7}=R^{8}=F$ 1k: $R^{1}=R^{2}=R^{3}=O M e, R^{6}=B r, R^{4}=R^{5}=R^{7}=R^{8}=H$ 1I: $R^{1}=R^{2}=R^{3}=O M e, R^{6}=M e, R^{4}=R^{5}=R^{7}=R^{8}=H$ 1m: $\mathrm{R}^{1}=\mathrm{R}^{3}=\mathrm{H}, \mathrm{R}^{2}=\mathrm{NO}_{2}, \mathrm{R}^{4}=\mathrm{OMe}, \mathrm{R}^{5}=\mathrm{R}^{6}=\mathrm{R}^{7}=\mathrm{R}^{8}=\mathrm{H}$ 1n: $R^{1}=R^{3}=H, R^{2}=B r, R^{4}=R^{5}=R^{6}=R^{7}=R^{8}=H$ 10: $R^{1}=R^{3}=H, R^{2}=B r, R^{4}=R^{7}=R^{8}=H, R^{5}=R^{6}=M e$

Scheme 2. Reagents and conditions: (i) EtOH, reflux, 4-8 h. 


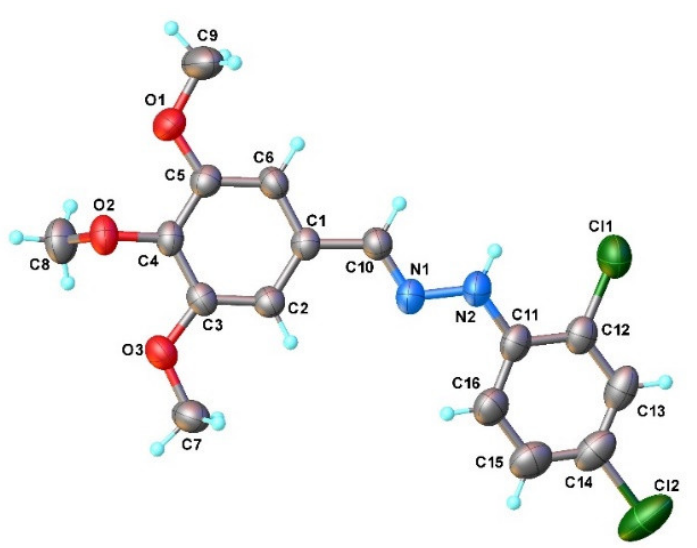

(a)

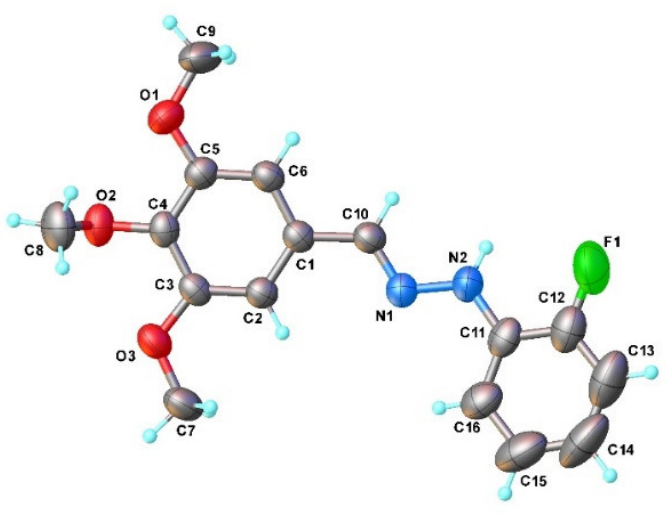

(b)

Figure 2. A view of the asymmetric part in the crystal structure of $\mathbf{1 e}(\mathbf{a})$ and $\mathbf{1 i}(\mathbf{b})$ with atom labeling and thermal ellipsoids at $50 \%$ level.

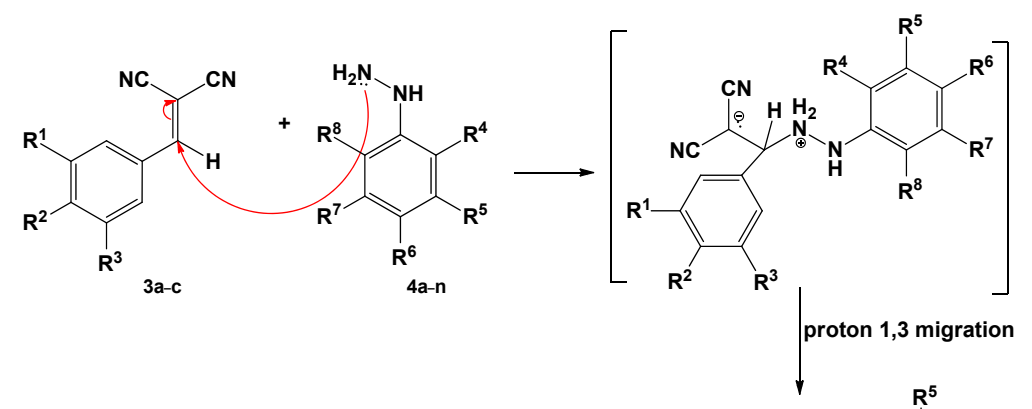<smiles>[R]c1cc(/C=N/Nc2c([2H])c([R])c([2H])c([2H])c2[2H])cc([TlH])c1[2H]</smiles>

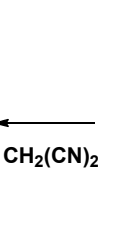

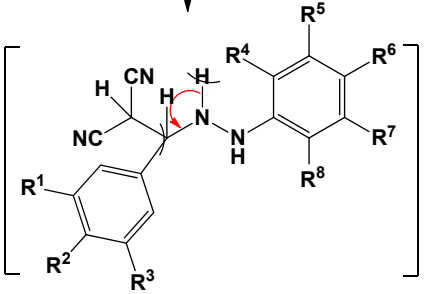

Scheme 3. Proposed mechanism for the formation of hydrazones 1a-o from benzylidenemalononitriles $3 \mathbf{a}-\mathbf{c}$ upon reaction with hydrazines $4 \mathbf{a}-\mathbf{n}$.

The structure of compounds $1 \mathbf{e}$ and $\mathbf{1} \mathbf{i}$ was demonstrated by single crystal X-ray diffraction method. According to X-ray crystallography, the two compounds are isostructural. They crystallize in the $P 2_{1} / c$ space group with close unit cell parameters (Table S1, see Supplementary Materials for full data). The asymmetric part of the unit cell (Figure 2a,b) comprises one molecule of $\mathbf{1 e}$ and $\mathbf{1 i}$ as a crystallographic independent unit, respectively. There are no co-crystallized solvent molecules in both crystals.

As expected, compounds $1 \mathbf{e}$ and $\mathbf{1 i}$ feature similar crystal structure packing. Indeed, for both crystals, the main crystal structure motif is described as a one-dimensional supramolecular array running along the $b$ axis, which is formed through intermolecular $\mathrm{NH} \cdots \mathrm{O}$ and $\mathrm{CH} \cdots \mathrm{O}$ hydrogen bonding. As an example, a view of the one-dimensional architecture in the crystal structure of $\mathbf{1 i}$ is shown in Figure 3.

A mechanism has been proposed for the formation of hydrazones 1a-o from benzylidenemalononitriles 3a-c (Scheme 3). The first step involved the classical nucleophilic attack of the marginal nitrogen of the hydrazine on the ethylenic carbon of the 2-cyano3 -aryl-acrylonitrile. The intermediate formed underwent a proton 1,3 migration. This allowed the formation of malononitrile as a leaving group and the formation of hydrazones (Schemes 2 and 3). 


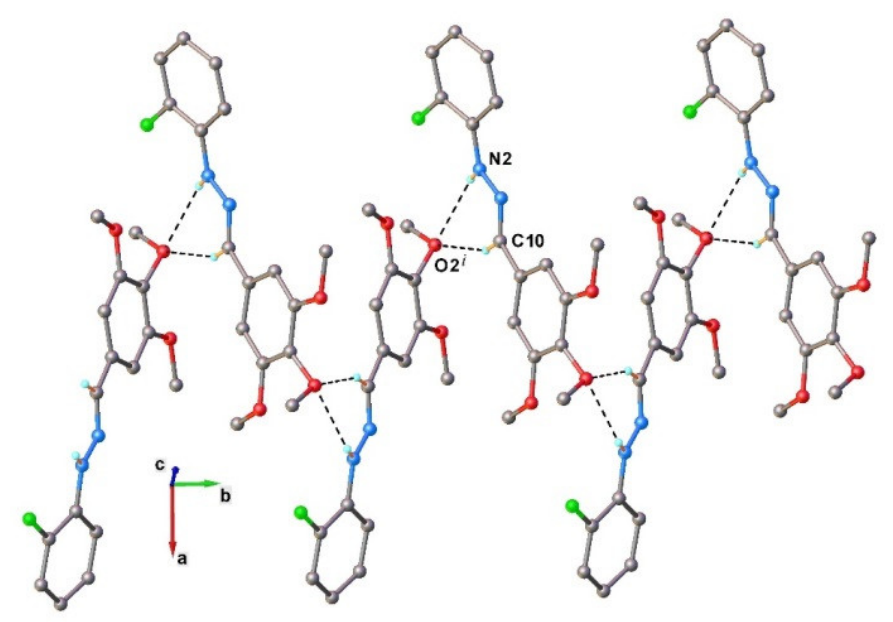

Figure 3. 1D supramolecular chain in the crystal structure of 1i. Non-relevant hydrogen atoms are not shown. H-bonds are drawn as black-dashed lines. Symmetry code: $i)-x,-0.5+y,-1.5-z$.

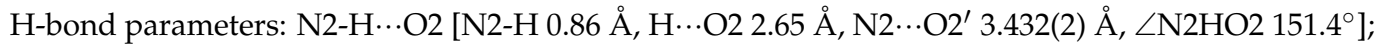

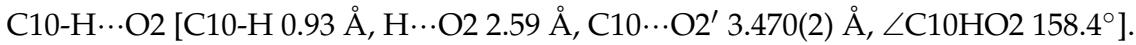

Primary antifungal screening study by whole cell growth inhibition assays, using all the synthesized hydrazones 1a-o at a single concentration of $32 \mu \mathrm{g} / \mathrm{mL}$, was realized in triplicate $(n=3)$. Hit confirmation of active compounds by whole cell growth inhibition assays was conducted as an eight-point dose response to determine the Minimum Inhibitory Concentration (MIC), in triplicate $(n=3)$. The inhibition of growth was measured against eight fungi strains: C. albicans SC5314, C. dubliniensis, C. glabrata, C. parapsilosis, C. albicans from mucoviscidosis patients (C. albicans (mucoviscidosis)), C. albicans resistant to echinocandins (C. albicans (R echinocandins)) and C. glabrata resistant to azoles (C. glabrata (R azoles)) (Table 1). The fungal strains were obtained from Pôle de Biologie Pathologie Génétique, Centre Hospitalier Universitaire (CHU) de Lille, France. Fluconazole was used as the positive reference in the assay. Samples were prepared in DMSO and water to a final testing concentration of $32 \mu \mathrm{g} / \mathrm{mL}$ and in triplicate $(n=3)$, keeping the final DMSO concentration to a maximum of $1 \%$ DMSO. All the sample preparation was performed using liquid handling robots. Only five hydrazones, $\mathbf{1 c}, \mathbf{1 d}, \mathbf{1 i}, \mathbf{1} \mathbf{k}$ and $\mathbf{1}$, displayed notable antifungal activity against tested Candida spp., with MIC values between 16 and $32 \mu \mathrm{g} / \mathrm{mL}$. The results are presented in Table 1 . All other synthesized hydrazones, $\mathbf{1 a}, \mathbf{1} \mathbf{b}, \mathbf{1 e}-\mathbf{h}, \mathbf{1} \mathbf{j}$ and $\mathbf{1 m}-\mathbf{o}$, were less active, with MIC values $>32 \mu \mathrm{g} / \mathrm{mL}$ (data not shown).

Table 1. MIC values of active hydrazones $\mathbf{1 c}, \mathbf{1 d}, \mathbf{1} \mathbf{i}, \mathbf{1 k}$ and $\mathbf{1 l}$ on Candida spp.

\begin{tabular}{|c|c|c|c|c|c|c|c|c|c|}
\hline \multirow[b]{2}{*}{ Entry } & \multicolumn{9}{|c|}{ MIC Values $(\mu \mathrm{g} / \mathrm{mL})$ on Candida spp. ${ }^{[\mathrm{a}, \mathrm{b}, \mathrm{c}, \mathrm{d}]}$} \\
\hline & Compound & $\begin{array}{l}\text { C. albicans } \\
\text { SC5314 }\end{array}$ & $\begin{array}{c}C . \\
\text { dubliniensis }\end{array}$ & C. glabrata & $\begin{array}{c}\text { C. } \\
\text { parapsilosis }\end{array}$ & C. tropicalis & $\begin{array}{l}\text { C. albicans } \\
\text { (Mucovisci- } \\
\text { dosis) }\end{array}$ & $\begin{array}{c}\text { C. albicans } \\
\text { (R echinocandins) }\end{array}$ & $\begin{array}{l}\text { C. glabrata } \\
\text { (R azoles) }\end{array}$ \\
\hline 1 & 1c & 32 & $>32^{[\mathrm{e}]}$ & 32 & 32 & $>32$ & $>32$ & $>32$ & 32 \\
\hline 2 & $1 d$ & 32 & $>32$ & 16 & $>32$ & $>32$ & $>32$ & $>32$ & 32 \\
\hline 3 & $1 \mathrm{i}$ & 32 & $>32$ & 32 & 32 & $>32$ & $>32$ & $>32$ & 32 \\
\hline 4 & 1k & 32 & $>32$ & 16 & 32 & 32 & $>32$ & $>32$ & $>32$ \\
\hline 5 & 11 & 32 & $>32$ & 16 & 32 & 32 & $>32$ & $>32$ & 32 \\
\hline 6 & Fluconazole & 0.5 & 0.5 & 0.5 & 0.5 & 0.5 & 0.5 & 0.5 & $>32$ \\
\hline
\end{tabular}

${ }^{[a]}$ In vitro inhibition percentage of pathogens. ${ }^{[b]}$ Values represent mean of three experiments. ${ }^{[c]}$ Compounds were tested at $32,16,8,4$ and $1 \mu \mathrm{g} / \mathrm{mL}$ concentration. ${ }^{[\mathrm{d}]}$ MIC values given in the table correspond to $\mathrm{MIC}_{99}$ (total growth inhibition of Candida spp.). ${ }^{[\mathrm{e}]} \mathrm{MIC}$ not calculated since total inhibition of Candida spp. was not obtained at $32 \mu \mathrm{g} / \mathrm{mL}$.

Active hydrazones $\mathbf{1 c}, \mathbf{1 d}, \mathbf{1 i}, \mathbf{1} \mathbf{k}$ and $\mathbf{1 1}$ share the same 3,4,5-trimethoxyphenyl unit and have the particularity of a monosubstitution on the other phenyl ring. Generally, the ortho-substitution by an electro-withdrawing group $(\mathrm{F}, \mathrm{Cl}$ and $\mathrm{Br}) \mathrm{in} \mathbf{\mathbf { 1 i }}, \mathbf{1 d}$ and $\mathbf{1 c}$, respectively, was the most favorable chemical modulation for the antifungal activity in the 
current work. The comparison of halogens reveals that the chlorine atom in hydrazone 1d was the most active, especially on C. glabrata $(\mathrm{MIC}=16 \mu \mathrm{g} / \mathrm{mL}$ ) compared to fluoro and bromo congeners $\mathbf{1 i}$ and $\mathbf{1 c}(\mathrm{MIC}=32 \mu \mathrm{g} / \mathrm{mL})$ (Table 1$)$. The trifluoromethyl substituent in hydrazone 1a resulted in dramatical loss of the antifungal potential (MIC $>32 \mu \mathrm{g} / \mathrm{mL}$ ). The para-bromo substitution in hydrazone 1k slightly decreased the antifungal potential on C. glabrata (R azoles) (MIC $>32 \mu \mathrm{g} / \mathrm{mL}$ ) but conserved the notable antifungal effect on $C$. glabrata $(\mathrm{MIC}=16 \mu \mathrm{g} / \mathrm{mL}$ ) and on C. tropicalis $(\mathrm{MIC}=32 \mu \mathrm{g} / \mathrm{mL})$ (Table 1). To be noted, only para-substituted compounds $\mathbf{1 k}$ and $\mathbf{1 1}$ displayed inhibition activity against $\mathrm{C}$. tropicalis $(\mathrm{MIC}=32 \mu \mathrm{g} / \mathrm{mL})$, while the ortho-substituted analogs were less active (MIC $>32 \mu \mathrm{g} / \mathrm{mL})$ (Table 1). The electron-donating substituents by inductive or mesomeric effect (Me or $\mathrm{OMe}$ ) in the ortho position of the phenyl unit were not tolerated on any of the tested fungi (MIC $>32 \mu \mathrm{g} / \mathrm{mL}$ for hydrazones $\mathbf{1 b}, \mathbf{1 g}$ and $\mathbf{1 m}$ ). The di- or polysubstitution of the same phenyl ring by both electron-withdrawing or electron-donating groups in hydrazones 1e, 1f, $\mathbf{1 j}$ and 10 were not favorable for antifungal activity (MIC $>32 \mu \mathrm{g} / \mathrm{mL}$ ). Finally, the replacement of the 3,4,5-trimethoxyphenyl unit by a 4-nitrophenyl or 4-bromophenyl moiety in hydrazones $\mathbf{1 m}-\mathbf{o}$ also abolished the antifungal activity against all tested Candida spp. (MIC > $32 \mu \mathrm{g} / \mathrm{mL}$ ). The 3,4,5-trimethoxyphenyl unit seemed essential to maintain the biological activity on C. albicans SC5314, C. glabrata, C. parapsilosis and C. glabrata resistant to azoles (MIC values of 16 and $32 \mu \mathrm{g} / \mathrm{mL}$, respectively). Diminished potential was registered on the clinical isolates of C. albicans (mucoviscidosis) and C. albicans resistant to echinocandins. Newly synthesized hydrazones generally showed more pronounced antifungal activity on strains of C. glabrata, including C. glabrata that is resistant to azoles (Table 1).

To verify the mammalian cytotoxicity of the newly identified antifungals presented herein, compounds $\mathbf{1 c}, \mathbf{1} \mathbf{d}, \mathbf{1 i}, \mathbf{1} \mathbf{k}$ and $\mathbf{1 1}$ were tested against human embryonic kidney cells (HEK293) at ten different concentrations (0.06 to $32 \mu \mathrm{g} / \mathrm{mL}$ ) (Figure 4). The highest concentration of $32 \mu \mathrm{g} / \mathrm{mL}$ tested corresponded to the concentration at which the compounds exhibit potent antifungal activity. Since compounds were dissolved in $0.1 \%$ DMSO in the stock solution for this assay, DMSO was used as a negative reference in the same test. As depicted in Figure 4, the concentration of $0.1 \%$ of DMSO is devoid of cytotoxic effect and is safe for compound solubilization, while the concentration of $20 \%$ of DMSO displayed high toxicity. This denotes the importance of the concentration of DMSO used to dissolve the experimental drugs so as not to have distorted effects due to the solvent. All tested compounds showed no toxicity in viable kidney HEK293 cells.

In addition, compounds $\mathbf{1 c}, \mathbf{1 d}, \mathbf{1} \mathbf{i}, \mathbf{1 k}$ and $\mathbf{1 1}$ have also been selected and evaluated for cell growth inhibition activity on the NCI-60 cancer cell lines panel. Molecules were tested at $3.65 \mu \mathrm{g} / \mathrm{mL}(10 \mu \mathrm{M})$ concentration (compound 1c), $3.21 \mu \mathrm{g} / \mathrm{mL}(10 \mu \mathrm{M})$ concentration (compound 1d), $3.04 \mu \mathrm{g} / \mathrm{mL}(10 \mu \mathrm{M})$ concentration (compound 1i), $3.65 \mu \mathrm{g} / \mathrm{mL}(10 \mu \mathrm{M})$ concentration (compound 1i) and $3.00 \mu \mathrm{g} / \mathrm{mL}(10 \mu \mathrm{M})$ concentration (compound 1k) and did not show any notable cytotoxic effect. The full one-dose mean graphs for antifungal agents $\mathbf{1 c}, \mathbf{1 d}, \mathbf{1 i}, \mathbf{1 k}$ and $\mathbf{1 1}$ are available in the supplementary data section associated with this article. 


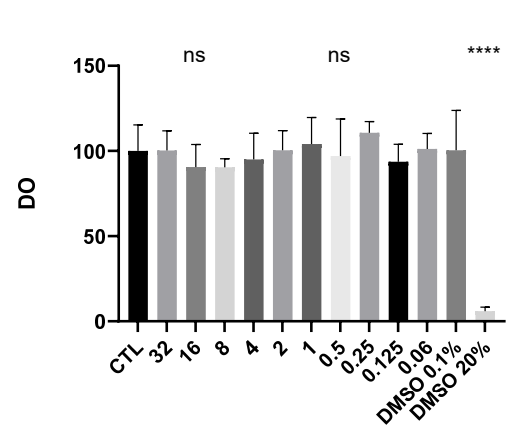

(a)

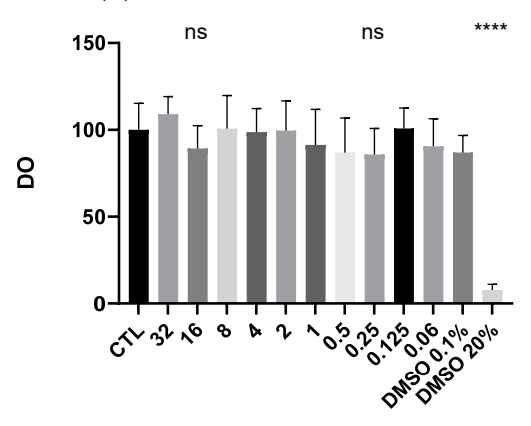

(d)

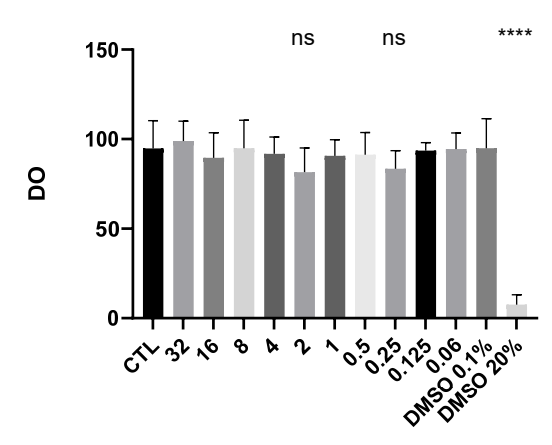

(b)



(c)

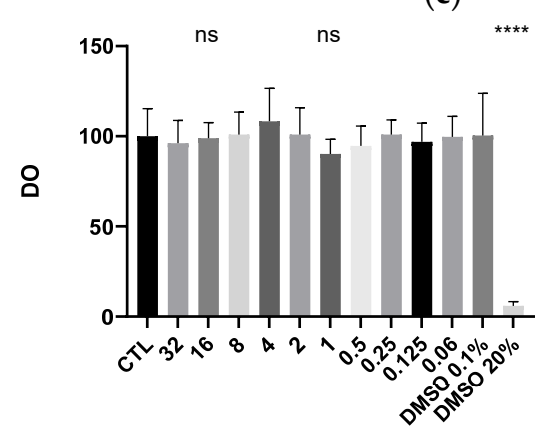

(e)

Figure 4. Evaluation of the cytotoxicity of experimental antifungals on HEK293 cells at different concentrations $(32 \mu \mathrm{g} / \mathrm{mL}$ to $0.06 \mu \mathrm{g} / \mathrm{mL}$ ): (a) hydrazone $\mathbf{1 c}$; (b) hydrazone $\mathbf{1 d}$; (c) hydrazone $\mathbf{1 i}$; (d) hydrazone 1k; (e) hydrazone 11. ns: no significance; $* * * *: p$ value $\leq 0.0001$.

\section{Materials and Methods}

Starting materials are commercially available and were used without further purification (suppliers: Carlo Erba Reagents S.A.S., Val-de-Reuil, France; Thermo Fisher Scientific Inc., Illkirch, France; Tokyo Chemical Industry Co., Ltd., Zwijndrecht, Belgium; and Sigma-Aldrich Co., Saint-Quentin-Fallavier, France). Melting points were measured on an MPA 100 OptiMelt $^{\circledR}$ apparatus (Stanford Research Systems, Sunnyvale, CA, USA) and are uncorrected. Nuclear magnetic resonance (NMR) spectra were acquired at $400 \mathrm{MHz}$ for ${ }^{1} \mathrm{H}-\mathrm{NMR}$, and at $100 \mathrm{MHz}$ for ${ }^{13} \mathrm{C}-\mathrm{NMR}$ on a Varian 400-MR spectrometer (Varian, Les Ulis, France) with tetramethylsilane (TMS) as internal standard, at room temperature (RT) or at $500 \mathrm{MHz}$ for ${ }^{1} \mathrm{H}-\mathrm{NMR}$, and at $125 \mathrm{MHz}$ for ${ }^{13} \mathrm{C}-\mathrm{NMR}$ on a Bruker Avance III $500 \mathrm{MHz}$ spectrometer (Bruker, Mannheim, Germany) with tetramethylsilane (TMS) as internal standard, at room temperature (RT). Chemical shifts $(\delta)$ are expressed in ppm relative to TMS. Splitting patterns are designed: s, singlet; $d$, doublet; dd, doublet of doublets; $\mathrm{t}$, triplet; q, quadruplet; quint, quintuplet; $\mathrm{m}$, multiplet; sym $\mathrm{m}$, symmetric multiplet; br s, broaden singlet; br $\mathrm{t}$, broaden triplet. Coupling constants $(J)$ are reported in Hertz $(\mathrm{Hz})$. The designation $\mathrm{Ph} 1$ in the ${ }^{13} \mathrm{C}-\mathrm{NMR}$ spectra description corresponds to the phenyl ring coming from the starting hydrazine, and $\mathrm{Ph} 2$ is the phenyl ring linked to $-\mathrm{CH}=\mathrm{N}$ group. Thin layer chromatography (TLC) was realized on Macherey Nagel silica gel plates (Macherey Nagel, Hoerdt, France) with fluorescent indicator and were visualized under a UV-lamp at $254 \mathrm{~nm}$ and $365 \mathrm{~nm}$. Elemental analyses (C, H, N) of new compounds were determined on a Thermo Electron apparatus (Thermo Fisher Scientific Inc., Illkirch, France) by "Pôle Chimie Moléculaire-Welience", Faculté des Sciences Mirande, Dijon, France.

\subsection{General Procedure for the Synthesis of Benzylidenemalononitriles (3a-c)}

A mixture of aldehyde (2a-c, 5.4-25.5 mmol, 1 equiv), malononitrile (5.4-25.5 mmol, 1 equiv) and $0.5 \mathrm{~mL}$ of piperidine in ethanol, was stirred at reflux for $6-8 \mathrm{~h}$. After cooling the reaction medium to room temperature, the obtained precipitate was filtered, washed 
with ethanol, and then recrystallized from ethanol to afford the pure expected product $(3 a-c)$.

\subsubsection{2-(3,4,5-trimethoxybenzylidene)malononitrile (3a)}

The general procedure was used with 3,4,5-trimethoxybenzaldehyde $(5.0 \mathrm{~g})$ and malononitrile $(1.4 \mathrm{~mL})$ to obtain pure compound $3 \mathrm{a}$ as a yellow solid $(5.6 \mathrm{~g}, 90 \%$ yield); $\mathrm{mp}(\mathrm{EtOH}) 119-121^{\circ} \mathrm{C}$ (lit. mp $120{ }^{\circ} \mathrm{C}$ ) [13]; $\mathrm{R}_{\mathrm{f}}$ (EtOAc:Cyclohexane 1:1) = 0.84; ${ }^{1} \mathrm{H}-\mathrm{NMR}$ $\left(\mathrm{CDCl}_{3}, 500 \mathrm{MHz}\right) \delta$ ppm $3.90\left(\mathrm{~s}, 6 \mathrm{H}, 2 \mathrm{OCH}_{3}\right), 3.97\left(\mathrm{~s}, 3 \mathrm{H}, \mathrm{OCH}_{3}\right), 7.18(\mathrm{~s}, 2 \mathrm{H}, 2 \mathrm{ArH}), 7.65$ $(\mathrm{s}, 1 \mathrm{H},=\mathrm{CH})$. Compound $3 \mathbf{a}$ exhibited the same NMR spectra as previously reported [13].

\subsubsection{2-(4-nitrobenzylidene)malononitrile (3b)}

The general procedure was used with 4-nitrobenzaldehyde (1.0 g) and malononitrile $(0.37 \mathrm{~mL})$ to obtain pure compound $3 \mathbf{b}$ as a brown solid $(1.04 \mathrm{~g}, 79 \%$ yield $) ; \mathrm{mp}(\mathrm{EtOH})$ 160-162 ${ }^{\circ} \mathrm{C} ; \mathrm{R}_{\mathrm{f}}\left(\right.$ EtOAc:Cyclohexane 1:1) = 0.83. ${ }^{1} \mathrm{H}-\mathrm{NMR}\left(\mathrm{CDCl}_{3}, 400 \mathrm{MHz}\right) \delta \mathrm{ppm} 7.88$ $(\mathrm{s}, 1 \mathrm{H},=\mathrm{CH}), 8.08(\mathrm{~d}, J=8.8 \mathrm{~Hz}, 2 \mathrm{H}, 2 \mathrm{ArH}), 8.39(\mathrm{~d}, J=8.8 \mathrm{~Hz}, 2 \mathrm{H}, 2 \mathrm{ArH})$. Compound 3c exhibited the same NMR spectra as previously reported [14].

\subsubsection{2-(4-bromobenzylidene)malononitrile (3c)}

The general procedure was used with 4-bromobenzaldehyde $(1.0 \mathrm{~g})$ and malononitrile $(0.3 \mathrm{~mL})$ to obtain pure compound $3 \mathrm{c}$ as a white solid $(1.1 \mathrm{~g}, 87 \%$ yield); $\mathrm{mp}(\mathrm{EtOH})$ 162-164 ${ }^{\circ} \mathrm{C}$ (lit. mp 165-166 ${ }^{\circ} \mathrm{C}$ ) [15]; $\mathrm{R}_{\mathrm{f}}$ (EtOAc:Cyclohexane 1:1) = 0.93. ${ }^{1} \mathrm{H}-\mathrm{NMR}$ (DMSO$\left.d_{6}, 500 \mathrm{MHz}\right) \delta$ ppm 7.81-7.86 (m, 4H, 4ArH), $8.51(\mathrm{~s}, 1 \mathrm{H},=\mathrm{CH})$. Compound 3c exhibited the same NMR spectra as previously reported [15].

\subsection{General Procedure for the Preparation of Hydrazone Derivatives (1a-o)}

A solution of benzylidenemalononitrile (3a-c, 1.6-2.5 mmol, 1 equiv.) and hydrazine (4a-n, 1.6-2.5 mmol, 1 equiv.) in ethanol was stirred at reflux for 4-8 h. After cooling the reaction medium to room temperature, the product precipitated was collected by filtration, washed with ethanol and purified by recrystallization from ethanol to obtain pure target hydrazone.

\subsubsection{1-(2-(trifluoromethyl)phenyl)-2-(3,4,5-trimethoxybenzylidene)hydrazine (1a)}

The general procedure was used with 2-(3,4,5-trimethoxybenzylidene)malononitrile $3 \mathrm{a}(0.4 \mathrm{~g})$ and 2-(trifluoromethyl)phenylhydrazine $4 \mathrm{a}(0.29 \mathrm{~g})$ to obtain pure compound 1a as a white solid $(0.46 \mathrm{~g}, 79 \%$ yield $) ; \mathrm{mp}(\mathrm{EtOH}) 147-148{ }^{\circ} \mathrm{C} ; \mathrm{R}_{\mathrm{f}}($ EtOAc:Cyclohexane $1: 1)=0.64 .{ }^{1} \mathrm{H}-\mathrm{NMR}\left(\mathrm{CDCl}_{3}, 500 \mathrm{MHz}\right) \delta \mathrm{ppm} 3.89\left(\mathrm{~s}, 3 \mathrm{H}, \mathrm{OCH}_{3}\right), 3.92\left(\mathrm{~s}, 6 \mathrm{H}, 2 \mathrm{OCH}_{3}\right)$, 6.89-6.92 (m, 3H, 3ArH), 7.47-7.50 (m, 2H, 2ArH), $7.73(\mathrm{~s}, 1 \mathrm{H},=\mathrm{CH}), 7.78(\mathrm{~d}, J=9.0 \mathrm{~Hz}, 1 \mathrm{H}$, $\mathrm{ArH}), 8.01(\mathrm{~s}, 1 \mathrm{H}, \mathrm{NH}) .{ }^{13} \mathrm{C}-\mathrm{NMR}\left(\mathrm{CDCl}_{3}, 125 \mathrm{MHz}\right) \delta \mathrm{ppm} 56.3\left(2 \mathrm{OCH}_{3}\right), 61.1\left(\mathrm{OCH}_{3}\right)$, 103.7 (2CH, 2CH-2,6-Ph2), 112.3 (q, J = 60.0, 30.0 Hz, CF $), 114.8$ (CH, CH-6-Ph1), 119.1 (CH, CH-5-Ph1), 125.0 (q, J = 541.2, $270.0 \mathrm{~Hz}, \mathrm{C}, \mathrm{C}-2-\mathrm{Ph} 1), 126.3$ (q, J = 11.2, $6.2 \mathrm{~Hz}, \mathrm{CH}$, CH-3-Ph1), 130.4 (C, C-1-Ph1), 133.3 (CH, CH-4-Ph1), 140.1 (=CH), 142.2 (C, C-4-Ph2), 142.3 (C, C-1-Ph2), 153.6 (2C, 2C-3,5-Ph2). Elemental analysis calcd (\%) for $\mathrm{C}_{17} \mathrm{H}_{17} \mathrm{~F}_{3} \mathrm{~N}_{2} \mathrm{O}_{3}$ : C 57.63, H 4.84, N 7.91; found: C 57.92, H 4.89, N 7.33.

\subsubsection{1-(2-methoxyphenyl)-2-(3,4,5-trimethoxybenzylidene)hydrazine (1b)}

The general procedure was used with 2-(3,4,5-trimethoxybenzylidene)malononitrile 3a $(0.4 \mathrm{~g})$ and 2-methoxyphenylhydrazine $4 \mathbf{b}(0.23 \mathrm{~g})$ to obtain pure compound $\mathbf{1 b}$ as a yellow solid (0.37 g, 71\% yield); $\mathrm{mp}(\mathrm{EtOH}) 179-180{ }^{\circ} \mathrm{C} ; \mathrm{R}_{\mathrm{f}}($ EtOAc:Cyclohexane 1:1) $=0.66$. ${ }^{1} \mathrm{H}-\mathrm{NMR}\left(\mathrm{CDCl}_{3}, 500 \mathrm{MHz}\right) \delta \mathrm{ppm} 3.88\left(\mathrm{~s}, 3 \mathrm{H}, \mathrm{OCH}_{3}\right), 3.89\left(\mathrm{~s}, 3 \mathrm{H}, \mathrm{OCH}_{3}\right), 3.92(\mathrm{~s}, 6 \mathrm{H}$, $\left.2 \mathrm{OCH}_{3}\right), 6.83-6.86(\mathrm{~m}, 2 \mathrm{H}, 2 \mathrm{ArH}), 6.91(\mathrm{~s}, 2 \mathrm{H}, 2 \mathrm{ArH}), 6.98(\mathrm{td}, J=7.0,2.0 \mathrm{~Hz}, 1 \mathrm{H}, \mathrm{ArH})$, $7.52(\mathrm{dd}, J=7.5,2.0 \mathrm{~Hz}, 1 \mathrm{H}, \mathrm{ArH}), 7.70(\mathrm{~s}, 1 \mathrm{H},=\mathrm{CH}), 8.07(\mathrm{~s}, 1 \mathrm{H}, \mathrm{NH}) .{ }^{13} \mathrm{C}-\mathrm{NMR}\left(\mathrm{CDCl}_{3}\right.$, $125 \mathrm{MHz}) \delta$ ppm $55.7\left(\mathrm{OCH}_{3}, \mathrm{OCH}_{3}-2-\mathrm{Ph} 1\right), 56.3\left(2 \mathrm{OCH}_{3}\right), 61.1\left(\mathrm{OCH}_{3}\right), 103.3(2 \mathrm{CH}, 2 \mathrm{CH}-$ 2,6-Ph2), 110.2 (CH, CH-6-Ph1), 112.5 (CH, CH-3-Ph1), 119.4 (CH, CH-4-Ph1), 121.7 (CH, CH-5-Ph1), 131.2 (C, C-1-Ph2), 134.3 (C, C-1-Ph1), 138.1 (=CH), 138.7 (C, C-2-Ph1), 145.3 (C, 
C-4-Ph2), 153.6 (2C, 2C-3,5-Ph2). Elemental analysis calcd (\%) for $\mathrm{C}_{17} \mathrm{H}_{20} \mathrm{~N}_{2} \mathrm{O}_{4}$ : C 64.54, $\mathrm{H}$ 6.37, N 8.86; found: C 64.87, H 6.52, N 9.02.

\subsubsection{1-(2-bromophenyl)-2-(3,4,5-trimethoxybenzylidene)hydrazine (1c)}

The general procedure was used with 2-(3,4,5-trimethoxybenzylidene)malononitrile $3 \mathrm{a}(0.4 \mathrm{~g})$ and 2-bromophenylhydrazine $4 \mathrm{c}(0.31 \mathrm{~g})$ to obtain pure compound $1 \mathrm{c}$ as a pink solid $(0.50 \mathrm{~g}, 83 \%$ yield $) ; \mathrm{mp}(\mathrm{EtOH}) 155-157^{\circ} \mathrm{C} ; \mathrm{R}_{\mathrm{f}}\left(\right.$ EtOAc:Cyclohexane 1:1) $=0.65 .{ }^{1} \mathrm{H}-$ NMR $\left(\mathrm{CDCl}_{3}, 500 \mathrm{MHz}\right) \delta \mathrm{ppm} 3.89\left(\mathrm{~s}, 3 \mathrm{H}, \mathrm{OCH}_{3}\right), 3.92\left(\mathrm{~s}, 6 \mathrm{H}, 2 \mathrm{OCH}_{3}\right), 6.74(\mathrm{td}, J=8.0$, $1.5 \mathrm{~Hz}, 1 \mathrm{H}, \mathrm{ArH}), 6.91(\mathrm{~s}, 2 \mathrm{H}, 2 \mathrm{ArH}), 7.28(\mathrm{td}, J=8.0,1.5 \mathrm{~Hz}, 1 \mathrm{H}, \mathrm{ArH}), 7.44(\mathrm{dd}, J=8,1.5 \mathrm{~Hz}$, $1 \mathrm{H}, \mathrm{ArH}), 7.58(\mathrm{dd}, J=8.0,1.5 \mathrm{~Hz}, 1 \mathrm{H}, \mathrm{ArH}), 7.76(\mathrm{~s}, 1 \mathrm{H},=\mathrm{CH}), 8.05(\mathrm{~s}, 1 \mathrm{H}, \mathrm{NH}) .{ }^{13} \mathrm{C}-\mathrm{NMR}$ $\left(\mathrm{CDCl}_{3}, 125 \mathrm{MHz}\right) \delta \mathrm{ppm} 56.3\left(2 \mathrm{OCH}_{3}\right), 61.1\left(\mathrm{OCH}_{3}\right), 103.5(2 \mathrm{CH}, 2 \mathrm{CH}-2,6-\mathrm{Ph} 2), 106.9(\mathrm{C}$, C-2-Ph1), 114.5 (CH, CH-6-Ph1), 120.7 (CH, CH-4-Ph1), 128.7 (CH, CH-5-Ph1), 130.6 (C, C-1-Ph2), 132.4 (CH, CH-3-Ph1), 139.0 (C, C-4-Ph2), 139.6 (=CH), 141.5 (C, C-1-Ph1), 153.6 (2C, 2C-3,5-Ph2). Elemental analysis calcd (\%) for $\mathrm{C}_{16} \mathrm{H}_{17} \mathrm{BrN}_{2} \mathrm{O}_{3}$ : C 52.62, H 4.69, N 7.67; found: C 52.76, H 4.90, N 7.95.

\subsubsection{1-(2-chlorophenyl)-2-(3,4,5-trimethoxybenzylidene)hydrazine (1d)}

The general procedure was used with 2-(3,4,5-trimethoxybenzylidene)malononitrile 3a $(0.4 \mathrm{~g})$ and 2-chlorophenylhydrazine $4 \mathbf{d}(0.23 \mathrm{~g})$ to obtain pure compound $1 \mathbf{d}$ as a pink solid $(0.37 \mathrm{~g}, 71 \%$ yield $) ; \mathrm{mp}(\mathrm{EtOH}) 164-166{ }^{\circ} \mathrm{C} ; \mathrm{R}_{\mathrm{f}}($ EtOAc:Cyclohexane $1: 1)=0.66 .{ }^{1} \mathrm{H}-$ $\operatorname{NMR}\left(\mathrm{CDCl}_{3}, 500 \mathrm{MHz}\right) \delta \mathrm{ppm} 3.86\left(\mathrm{~s}, 3 \mathrm{H}, \mathrm{OCH}_{3}\right), 3.92\left(\mathrm{~s}, 6 \mathrm{H}, 2 \mathrm{OCH}_{3}\right), 6.80(\mathrm{td}, J=8.0$, $1.5 \mathrm{~Hz}, 1 \mathrm{H}, \operatorname{ArH}), 6.90(\mathrm{~s}, 2 \mathrm{H}, 2 \mathrm{ArH}), 7.23-7.29(\mathrm{~m}, 2 \mathrm{H}, 2 \mathrm{ArH}), 7.60(\mathrm{dd}, J=8.0,1.5 \mathrm{~Hz}, 1 \mathrm{H}$, $\mathrm{ArH}), 7.73(\mathrm{~s}, 1 \mathrm{H},=\mathrm{CH}), 8.05(\mathrm{~s}, 1 \mathrm{H}, \mathrm{NH}) .{ }^{13} \mathrm{C}-\mathrm{NMR}\left(\mathrm{CDCl}_{3}, 125 \mathrm{MHz}\right) \delta \mathrm{ppm} 56.2\left(2 \mathrm{OCH}_{3}\right)$, $61.1\left(\mathrm{OCH}_{3}\right), 103.5$ (2CH, 2CH-2,6-Ph2), 114.2 (CH, CH-6-Ph1), 117.0 (C, C-2-Ph1), 120.1 (CH, CH-5-Ph1), 128.0 (CH, CH-3-Ph1), 129.2 (CH, CH-4-Ph1), 130.6 (C, C-1-Ph2), 139.0 (C, $\mathrm{C}-4-\mathrm{Ph} 2), 139.6(=\mathrm{CH}), 140.6$ (C, C-1-Ph1), 153.6 (2C, 2C-3,5-Ph2). Elemental analysis calcd (\%) for $\mathrm{C}_{16} \mathrm{H}_{17} \mathrm{ClN}_{2} \mathrm{O}_{3}$ : C 59.91, H 5.34, N 8.73; found: C 60.22, H 5.66, N 8.98.

\subsubsection{1-(2,4-dichlorophenyl)-2-(3,4,5-trimethoxybenzylidene)hydrazine (1e)}

The general procedure was used with 2-(3,4,5-trimethoxybenzylidene)malononitrile $3 \mathbf{a}(0.4 \mathrm{~g})$ and 2,4-dichlorophenylhydrazine $4 \mathbf{e}(0.29 \mathrm{~g})$ to obtain pure compound $\mathbf{1 e}$ as a white solid $(0.46 \mathrm{~g}, 79 \%$ yield $) ; \mathrm{mp}(\mathrm{EtOH}) 185-187^{\circ} \mathrm{C} ; \mathrm{R}_{\mathrm{f}}($ EtOAc:Cyclohexane 1:1) $=0.66$. ${ }^{1} \mathrm{H}-\mathrm{NMR}\left(\mathrm{CDCl}_{3}, 500 \mathrm{MHz}\right) \delta \mathrm{ppm} 3.88\left(\mathrm{~s}, 3 \mathrm{H}, \mathrm{OCH}_{3}\right), 3.90(\mathrm{~s}, 6 \mathrm{H}, 2 \mathrm{OCH} 3), 6.87(\mathrm{~s}, 2 \mathrm{H}$, $2 \mathrm{ArH}), 7.18(\mathrm{dd}, J=8.5,2.0 \mathrm{~Hz}, 1 \mathrm{H}, \operatorname{Ar} H), 7.25(\mathrm{~d}, J=2.0 \mathrm{~Hz}, 1 \mathrm{H}, \operatorname{ArH}), 7.50(\mathrm{~d}, J=8.5 \mathrm{~Hz}$, $1 \mathrm{H}, \mathrm{ArH}), 7.69(\mathrm{~s}, 1 \mathrm{H},=\mathrm{CH}), 7.96(\mathrm{~s}, 1 \mathrm{H}, \mathrm{NH}) .{ }^{13} \mathrm{C}-\mathrm{NMR}\left(\mathrm{CDCl}_{3}, 125 \mathrm{MHz}\right) \delta \mathrm{ppm} 56.2$ $\left(2 \mathrm{OCH}_{3}\right), 61.0\left(\mathrm{OCH}_{3}\right), 103.5(2 \mathrm{CH}, 2 \mathrm{CH}-2,6-\mathrm{Ph} 2), 114.9(\mathrm{CH}, \mathrm{CH}-6-\mathrm{Ph}-1), 117.1$ (C, C-2-Ph1), 124.0 (C, C-4-Ph1), 128.1 (CH, CH-5-Ph1), 128.7 (CH, CH-3-Ph1), 130.3 (C, C-1-Ph2), 139.1 (C, C-4-Ph2), 139.4 (C, C-1-Ph-1), 140.2 (=CH), 153.5 (2C, 2C-3,5-Ph2). Elemental analysis calcd (\%) for $\mathrm{C}_{16} \mathrm{H}_{16} \mathrm{Cl}_{2} \mathrm{~N}_{2} \mathrm{O}_{3}$ : C 54.10, $\mathrm{H} 4.54, \mathrm{~N}$ 7.89; found: C 54.29, H 4.79, $\mathrm{N}$ 8.01.

\subsubsection{1-(2,4-difluorophenyl)-2-(3,4,5-trimethoxybenzylidene)hydrazine (1f)}

The general procedure was used with 2-(3,4,5-trimethoxybenzylidene)malononitrile 3a $(0.4 \mathrm{~g})$ and 2,4-difluorophenylhydrazine $4 \mathrm{f}(0.24 \mathrm{~g})$ to obtain pure compound $\mathbf{1 f}$ as a yellow solid $(0.34 \mathrm{~g}, 65 \%$ yield $) ; \mathrm{mp}(\mathrm{EtOH}) 185-188^{\circ} \mathrm{C} ; \mathrm{R}_{\mathrm{f}}($ EtOAc:Cyclohexane $1: 1)=0.53$ ${ }^{1} \mathrm{H}-\mathrm{NMR}\left(\mathrm{DMSO}-d_{6}, 500 \mathrm{MHz}\right) \delta \mathrm{ppm} 3.69\left(\mathrm{~s}, 3 \mathrm{H}, \mathrm{OCH}_{3}\right), 3.84\left(\mathrm{~s}, 6 \mathrm{H}, 2 \mathrm{OCH}_{3}\right), 6.95(\mathrm{~s}, 2 \mathrm{H}$, $2 \mathrm{ArH}), 6.99(\mathrm{td}, J=9.0,2.0 \mathrm{~Hz}, 1 \mathrm{H}, \mathrm{ArH}), 7.18(\mathrm{td}, J=9.0,2.0 \mathrm{~Hz}, 1 \mathrm{H}, \mathrm{ArH}), 7.53(\mathrm{td}, J=9.0$, $2.0 \mathrm{~Hz}, 1 \mathrm{H}, \mathrm{ArH}), 8.03(\mathrm{~s}, 1 \mathrm{H},=\mathrm{CH}), 10.18(\mathrm{~s}, 1 \mathrm{H}, \mathrm{NH}) .{ }^{13} \mathrm{C}-\mathrm{NMR}$ (DMSO- $\left.d_{6}, 125 \mathrm{MHz}\right) \delta$ ppm $55.9\left(2 \mathrm{OCH}_{3}\right), 60.1\left(\mathrm{OCH}_{3}\right), 103.1(2 \mathrm{CH}, 2 \mathrm{CH}-2,6-\mathrm{Ph} 2), 103.8(\mathrm{CH}, \mathrm{CH}-3-\mathrm{Ph} 1), 111.4$ (dd, J = 21.2, $2.5 \mathrm{~Hz}, \mathrm{CH}, \mathrm{CH}-5-\mathrm{Ph} 1), 114.2$ (q, J = 8.7, $5.0 \mathrm{~Hz}, \mathrm{CH}, \mathrm{CH}-6-\mathrm{Ph} 1), 130.5$ (q, $J=10.0,2.5 \mathrm{~Hz}, \mathrm{C}, \mathrm{C}-1-\mathrm{Ph} 1), 131.1$ (C, C-1-Ph2), 138.0 (C, C-4-Ph2), 139.4 (=CH), 148.4 (dd, $J=240.0,11.2 \mathrm{~Hz}, \mathrm{C}, \mathrm{C}-2-\mathrm{Ph} 1), 153.2$ (2C, 2C-3,5-Ph2), 154.7 (dd, J = 235.0, $10.0 \mathrm{~Hz}, \mathrm{C}$, C-4-Ph1). Elemental analysis calcd (\%) for $\mathrm{C}_{16} \mathrm{H}_{16} \mathrm{~F}_{2} \mathrm{~N}_{2} \mathrm{O}_{3}$ : C 59.62, H 5.00, N 8.69; found: C 59.90, H 5.23, N 8.88. 


\subsubsection{1-(o-tolyl)-2-(3,4,5-trimethoxybenzylidene)hydrazine (19)}

The general procedure was used with 2-(3,4,5-trimethoxybenzylidene)malononitrile $3 \mathrm{a}(0.4 \mathrm{~g})$ and $o$-tolylhydrazine $4 \mathrm{~g}(0.20 \mathrm{~g})$ to obtain pure compound $1 \mathrm{~g}$ as a yellow solid $\left(0.43 \mathrm{~g}\right.$, 88\% yield); $\mathrm{mp}(\mathrm{EtOH}) 200-202{ }^{\circ} \mathrm{C} ; \mathrm{R}_{\mathrm{f}}$ (EtOAc:Cyclohexane 1:1) $=0.63 .{ }^{1} \mathrm{H}-\mathrm{NMR}$ $\left(\mathrm{DMSO}_{-} d_{6}, 500 \mathrm{MHz}\right) \delta \mathrm{ppm} 2.19\left(\mathrm{~s}, 3 \mathrm{H}, \mathrm{CH}_{3}\right), 3.75\left(\mathrm{~s}, 3 \mathrm{H}, \mathrm{OCH}_{3}\right), 3.84\left(\mathrm{~s}, 6 \mathrm{H}, 2 \mathrm{OCH}_{3}\right)$, $6.66(\mathrm{t}, J=7.5 \mathrm{~Hz}, 1 \mathrm{H}, \operatorname{ArH}), 6.84(\mathrm{~s}, 2 \mathrm{H}, 2 \mathrm{ArH}), 6.97(\mathrm{~d}, J=7.5 \mathrm{~Hz}, 1 \mathrm{H}, \operatorname{ArH}), 7.07(\mathrm{t}$, $J=7.5 \mathrm{~Hz}, 1 \mathrm{H}, \mathrm{ArH}), 7.41(\mathrm{~d}, J=7.5 \mathrm{~Hz}, 1 \mathrm{H}, \mathrm{ArH}), 7.90(\mathrm{~s}, 1 \mathrm{H},=\mathrm{CH}), 8.85(\mathrm{br} \mathrm{s}, 1 \mathrm{H}, \mathrm{NH})$. ${ }^{13} \mathrm{C}-\mathrm{NMR}\left(\mathrm{DMSO}-d_{6}, 125 \mathrm{MHz}\right) \delta \mathrm{ppm} 17.1\left(\mathrm{CH}_{3}\right), 55.5\left(2 \mathrm{OCH}_{3}\right), 60.1\left(\mathrm{OCH}_{3}\right), 102.4(2 \mathrm{CH}$, 2CH-2,6-Ph2), 112.0 (CH, CH-6-Ph1), 118.6 (CH, CH-5-Ph1), 120.3 (C, C-2-Ph1), 126.4 (CH, CH-4-Ph1), 129.8 (CH, CH-3-Ph1), 131.2 (C, C-1-Ph2), 137.5 (C, C-4-Ph2), 137.6 (=CH), 142.7 (C, C-1-Ph1), 152.8 (2C, 2C-3,5-Ph2). Elemental analysis calcd (\%) for $\mathrm{C}_{17} \mathrm{H}_{20} \mathrm{~N}_{2} \mathrm{O}_{3}$ : C 67.98, H 6.71, N 9.33; found: C 68.19, H 6.93, N 9.55.

\subsubsection{1-(4-chlorophenyl)-2-(3,4,5-trimethoxybenzylidene)hydrazine (1h)}

The general procedure was used with 2-(3,4,5-trimethoxybenzylidene)malononitrile $3 \mathrm{a}(0.4 \mathrm{~g})$ and 4 -chlorophenylhydrazine $4 \mathrm{~h}(0.23 \mathrm{~g})$ to obtain pure compound $\mathbf{1 h}$ as a yellow solid $\left(0.41 \mathrm{~g}\right.$, 79\% yield); $\mathrm{mp}(\mathrm{EtOH}) 156-158^{\circ} \mathrm{C} ; \mathrm{R}_{\mathrm{f}}($ EtOAc:Cyclohexane $1: 1)=0.66 .{ }^{1} \mathrm{H}-$ $\operatorname{NMR}\left(\mathrm{CDCl}_{3}, 500 \mathrm{MHz}\right) \delta \mathrm{ppm} 3.88\left(\mathrm{~s}, 3 \mathrm{H}, \mathrm{OCH}_{3}\right), 3.89\left(\mathrm{~s}, 6 \mathrm{H}, 2 \mathrm{OCH}_{3}\right), 6.85(\mathrm{~s}, 2 \mathrm{H}, 2 \mathrm{ArH})$, $7.01(\mathrm{~d}, J=9.0 \mathrm{~Hz}, 2 \mathrm{H}, 2 \mathrm{ArH}), 7.20(\mathrm{~d}, J=9.0 \mathrm{~Hz}, 2 \mathrm{H}, 2 \mathrm{ArH}), 7.51(\mathrm{~s}, 1 \mathrm{H},=\mathrm{CH}), 7.73(\mathrm{br} \mathrm{s}$, $1 \mathrm{H}, \mathrm{NH}) .{ }^{13} \mathrm{C}-\mathrm{NMR}\left(\mathrm{CDCl}_{3}, 125 \mathrm{MHz}\right) \delta \mathrm{ppm} 56.2\left(2 \mathrm{OCH}_{3}\right), 61.0\left(\mathrm{OCH}_{3}\right), 103.3(2 \mathrm{CH}, 2 \mathrm{CH}-$ 2,6-Ph2), 113.9 (2CH, 2CH-2,6-Ph1), 124.5 (C, C-4-Ph1), 129.2 (2CH, 2CH-3,5-Ph1), 130.9 (C, C-1-Ph2), 137.9 (=CH), 138.7 (C, C-4-Ph2), 143.4 (C, C-1-Ph1), 153.5 (2C, 2C-3,5-Ph2). Elemental analysis calcd (\%) for $\mathrm{C}_{16} \mathrm{H}_{17} \mathrm{ClN}_{2} \mathrm{O}_{3}$ : C 59.91, $\mathrm{H} 5.34, \mathrm{~N} 8.73$; found: $\mathrm{C} 60.26, \mathrm{H}$ $5.59, \mathrm{~N} 9.01$.

\subsubsection{1-(2-fluorophenyl)-2-(3,4,5-trimethoxybenzylidene)hydrazine (1i)}

The general procedure was used with 2-(3,4,5-trimethoxybenzylidene)malononitrile $3 \mathrm{a}(0.4 \mathrm{~g})$ and 2-fluorophenylhydrazine $4 \mathbf{i}(0.21 \mathrm{~g})$ to obtain pure compound $\mathbf{1 i}$ as a pink solid $(0.37 \mathrm{~g}$, $75 \%$ yield $) ; \mathrm{mp}(\mathrm{EtOH}) 145-147^{\circ} \mathrm{C} ; \mathrm{R}_{\mathrm{f}}($ EtOAc:Cyclohexane $1: 1)=0.61 .{ }^{1} \mathrm{H}$ $\operatorname{NMR}\left(\mathrm{CDCl}_{3}, 500 \mathrm{MHz}\right) \delta \mathrm{ppm} 3.88\left(\mathrm{~s}, 3 \mathrm{H}, \mathrm{OCH}_{3}\right), 3.91\left(\mathrm{~s}, 6 \mathrm{H}, 2 \mathrm{OCH}_{3}\right), 6.77-6.81(\mathrm{~m}$, $1 \mathrm{H}, \operatorname{ArH}), 6.89(\mathrm{~s}, 2 \mathrm{H}, 2 \mathrm{ArH}), 7.01-7.05(\mathrm{~m}, 1 \mathrm{H}, \operatorname{ArH}), 7.11(\mathrm{t}, J=8.0 \mathrm{~Hz}, 1 \mathrm{H}, \operatorname{ArH}), 7.59$ $(\mathrm{t}, J=8.0 \mathrm{~Hz}, 1 \mathrm{H}, \mathrm{ArH}), 7.66(\mathrm{~s}, 1 \mathrm{H},=\mathrm{CH}), 7.79(\mathrm{~d}, J=2.5 \mathrm{~Hz}, 1 \mathrm{H}, \mathrm{NH}) .{ }^{13} \mathrm{C}-\mathrm{NMR}\left(\mathrm{CDCl}_{3}\right.$, $125 \mathrm{MHz}) \delta \mathrm{ppm} 56.2\left(2 \mathrm{OCH}_{3}\right), 61.0\left(\mathrm{OCH}_{3}\right), 103.4(2 \mathrm{CH}, 2 \mathrm{CH}-2,6-\mathrm{Ph} 2), 114.5(\mathrm{~d}, J=2.5 \mathrm{~Hz}$, CH, CH-3-Ph1), 114.9 (d, J = 17.5 Hz, CH, CH-5-Ph1), 119.5 (d, J = 7.5 Hz, CH, CH-4-Ph1), 124.9 (d, J = 3.7 Hz, CH, CH-6-Ph1), 130.7 (C, C-1-Ph2), 133.1 (d, J = 8.7 Hz, C-1-Ph1), 138.9 (C, C-4-Ph2), $139.3(=\mathrm{CH}), 149.7$ (d, J = 237.5 Hz, C, C-2-Ph1), 153.6 (2C, 2C-3,5-Ph2). Elemental analysis calcd (\%) for $\mathrm{C}_{16} \mathrm{H}_{17} \mathrm{FN}_{2} \mathrm{O}_{3}$ : C 63.15, $\mathrm{H}$ 5.63, N 9.21; found: $\mathrm{C} 63.40, \mathrm{H}$ $5.89, \mathrm{~N} 9.39$.

\subsubsection{1-(pentafluorophenyl)-2-(3,4,5-trimethoxybenzylidene)hydrazine (1j)}

The general procedure was used with 2-(3,4,5-trimethoxybenzylidene)malononitrile $3 \mathbf{a}(0.4 \mathrm{~g})$ and pentafluorophenylhydrazine $4 \mathbf{j}(0.32 \mathrm{~g})$ to obtain pure compound $\mathbf{1 j}$ as an orange solid with the same NMR spectra as previously described [16] ( $0.47 \mathrm{~g}, 77 \%$ yield); $\mathrm{mp}(\mathrm{EtOH}) 220-223{ }^{\circ} \mathrm{C} ; \mathrm{R}_{\mathrm{f}}\left(\right.$ EtOAc:Cyclohexane 1:1) $=0.45 .{ }^{1} \mathrm{H}-\mathrm{NMR}\left(\mathrm{DMSO}-d_{6}, 500 \mathrm{MHz}\right)$ $\delta$ ppm $3.68\left(\mathrm{~s}, 3 \mathrm{H}, \mathrm{OCH}_{3}\right), 3.80\left(\mathrm{~s}, 6 \mathrm{H}, 3 \mathrm{OCH}_{3}\right), 6.90(\mathrm{~s}, 2 \mathrm{H}, 2 \mathrm{ArH}), 8.01(\mathrm{~s}, 1 \mathrm{H},=\mathrm{CH}), 10.28$ $(\mathrm{s}, 1 \mathrm{H}, \mathrm{NH}) .{ }^{13} \mathrm{C}-\mathrm{NMR}\left(\mathrm{DMSO}-d_{6}, 125 \mathrm{MHz}\right) \delta \mathrm{ppm} 55.8\left(2 \mathrm{OCH}_{3}\right), 60.1\left(\mathrm{OCH}_{3}\right), 103.2(2 \mathrm{CH}$, 2CH-2,6-Ph2), 121.3 (C, C-F), 130.4 (C, C-1-Ph2), 132.8 (C, C-F), 134.7 (C, C-F), 136.5 (C, C-F), 136.8 (C, C-F), 138.3 (C, C-1-Ph1), 138.8 (C, C-4-Ph2), 141.8 (=CH), 153.2 (2C, 2C-3,5-Ph2). Elemental analysis calcd (\%) for $\mathrm{C}_{16} \mathrm{H}_{13} \mathrm{~F}_{5} \mathrm{~N}_{2} \mathrm{O}_{3}$ : C 51.07, H 3.48, N 7.44; found: $\mathrm{C} 51.25, \mathrm{H}$ 3.61, N 7.69.

\subsubsection{1-(4-bromophenyl)-2-(3,4,5-trimethoxybenzylidene)hydrazine (1k)}

The general procedure was used with 2-(3,4,5-trimethoxybenzylidene)malononitrile 3a $(0.4 \mathrm{~g})$ and 4 -bromophenylhydrazine $4 \mathbf{k}(0.31 \mathrm{~g})$ to obtain pure compound $1 \mathbf{k}$ as a 
white solid (0.44 g, 73\% yield); $\mathrm{mp}(\mathrm{EtOH}) 152-155^{\circ} \mathrm{C} ; \mathrm{R}_{\mathrm{f}}($ EtOAc:Cyclohexane 1:1) $=0.92$. ${ }^{1} \mathrm{H}-\mathrm{NMR}\left(\mathrm{CDCl}_{3}, 500 \mathrm{MHz}\right) \delta \mathrm{ppm} 3.88\left(\mathrm{~s}, 3 \mathrm{H}, \mathrm{OCH}_{3}\right), 3.91\left(\mathrm{~s}, 6 \mathrm{H}, 2 \mathrm{OCH}_{3}\right), 6.87(\mathrm{~s}, 2 \mathrm{H}$, 2ArH), $6.97(\mathrm{~d}, J=8.0 \mathrm{~Hz}, 2 \mathrm{H}, 2 \mathrm{ArH}), 7.35(\mathrm{~d}, J=8.0 \mathrm{~Hz}, 2 \mathrm{H}, 2 \mathrm{ArH}), 7.56(\mathrm{~s}, 1 \mathrm{H},=\mathrm{CH}), 7.67$ $(\mathrm{s}, 1 \mathrm{H}, \mathrm{NH}) .{ }^{13} \mathrm{C}-\mathrm{NMR}\left(\mathrm{CDCl}_{3}, 125 \mathrm{MHz}\right) \delta \mathrm{ppm} 56.2\left(2 \mathrm{OCH}_{3}\right), 61.0\left(\mathrm{OCH}_{3}\right), 103.2(2 \mathrm{CH}$, 2CH-2,6-Ph2), 111.8 (C, C-4-Ph1), 114.3 (2CH, 2CH-2,6-Ph1), 130.7 (C, C-1-Ph2), 132.1 (2CH, 2CH-3,5-Ph1), 137.9 (=CH), 138.7 (C, C-4-Ph2), 143.7 (C, C-1-Ph1), 153.5 (2C, 2C-3,5-Ph2). Elemental analysis calcd (\%) for $\mathrm{C}_{16} \mathrm{H}_{17} \mathrm{BrN}_{2} \mathrm{O}_{3}$ : C 52.62, $\mathrm{H} 4.69, \mathrm{~N} 7.67$; found: $\mathrm{C} 52.81, \mathrm{H}$ 4.95, N 7.88.

\subsubsection{1-( $p$-tolyl)-2-(3,4,5-trimethoxybenzylidene)hydrazine (11)}

The general procedure was used with 2-(3,4,5-trimethoxybenzylidene)malononitrile 3a $(0.4 \mathrm{~g})$ and $p$-tolylhydrazine $4 \mathrm{l}(0.20 \mathrm{~g})$ to obtain pure compound $\mathbf{1 1}$ as a yellow solid $(0.27 \mathrm{~g}, 55 \%$ yield $) ; \mathrm{mp}(\mathrm{EtOH}) 172-174{ }^{\circ} \mathrm{C} ; \mathrm{R}_{\mathrm{f}}($ EtOAc:Cyclohexane $1: 1)=0.82 .{ }^{1} \mathrm{H}-\mathrm{NMR}$ $\left(\mathrm{CDCl}_{3}, 500 \mathrm{MHz}\right) \delta$ ppm $2.38\left(\mathrm{~s}, 3 \mathrm{H}, \mathrm{CH}_{3}\right), 3.87\left(\mathrm{~s}, 9 \mathrm{H}, 3 \mathrm{OCH}_{3}\right), 5.53(\mathrm{~s}, 1 \mathrm{H}, \mathrm{NH}), 6.66$ $(\mathrm{s}, 2 \mathrm{H}, 2 \mathrm{ArH}), 7.20(\mathrm{~d}, J=8.0 \mathrm{~Hz}, 2 \mathrm{H}, 2 \mathrm{ArH}), 7.48(\mathrm{~d}, J=8.0 \mathrm{~Hz}, 2 \mathrm{H}, 2 \mathrm{ArH}) .{ }^{13} \mathrm{C}-\mathrm{NMR}$ $\left(\mathrm{CDCl}_{3}, 125 \mathrm{MHz}\right) \delta \mathrm{ppm} 21.5\left(\mathrm{CH}_{3}\right), 56.2\left(2 \mathrm{OCH}_{3}\right), 60.9\left(\mathrm{OCH}_{3}\right), 85.7(=\mathrm{CH}), 106.1(2 \mathrm{CH}$, 2CH-2,6-Ph2), 122.4 (2CH, 2CH-2,6-Ph1), 129.7 (2CH, 2CH-3,5-Ph1), 133.1 (C, C-1-Ph2), 137.4 (C, C-4-Ph1), 141.4 (C, C-4-Ph2), 150.3 (C, C-1-Ph1), 153.1 (2C, 2C-3,5-Ph2). Elemental analysis calcd (\%) for $\mathrm{C}_{17} \mathrm{H}_{20} \mathrm{~N}_{2} \mathrm{O}_{3}$ : C 67.98, $\mathrm{H}$ 6.71, N 9.33; found: C 68.07, H 6.85, N 9.50.

\subsubsection{1-(2-methoxyphenyl)-2-(4-nitrobenzylidene)hydrazine (1m)}

The general procedure was used with 2-(4-nitrobenzylidene)malononitrile $3 \mathbf{b}$ (0.5 g) and 2-methoxyphenylhydrazine $4 \mathrm{~b}(0.34 \mathrm{~g})$ to obtain pure compound $\mathbf{1 m}$ as a dark red solid $(0.46 \mathrm{~g}, 68 \%$ yield $) ; \mathrm{mp}(\mathrm{EtOH}) 165-167{ }^{\circ} \mathrm{C} ; \mathrm{R}_{\mathrm{f}}($ EtOAc:Cyclohexane $1: 1)=0.49 .{ }^{1} \mathrm{H}-$ NMR (DMSO- $\left.d_{6}, 500 \mathrm{MHz}\right) \delta$ ppm $3.86\left(\mathrm{~s}, 3 \mathrm{H}, \mathrm{OCH}_{3}\right), 6.83(\mathrm{t}, J=7.5 \mathrm{~Hz}, 1 \mathrm{H}, \mathrm{ArH}), 6.92$ $(\mathrm{t}, J=7.5 \mathrm{~Hz}, 1 \mathrm{H}, \mathrm{ArH}), 6.97(\mathrm{~d}, J=8.0 \mathrm{~Hz}, 1 \mathrm{H}, \mathrm{ArH}), 7.46(\mathrm{dd}, J=8.0,1.5 \mathrm{~Hz}, 1 \mathrm{H}, \mathrm{ArH})$, $7.82(\mathrm{dd}, J=9.0,2.0 \mathrm{~Hz}, 2 \mathrm{H}, 2 \mathrm{ArH}), 8.21(\mathrm{dd}, J=9.0,2.0 \mathrm{~Hz}, 3 \mathrm{H}, 2 \mathrm{ArH}+=\mathrm{CH}), 10.3(\mathrm{~s}, 1 \mathrm{H}$, $\mathrm{NH}) .{ }^{13} \mathrm{C}-\mathrm{NMR}\left(\mathrm{DMSO}-d_{6}, 125 \mathrm{MHz}\right) \delta \mathrm{ppm} 55.6\left(\mathrm{OCH}_{3}\right), 111.1(\mathrm{CH}, \mathrm{CH}-3-\mathrm{Ph} 1), 112.3$ (CH, CH-6-Ph1), 120.0 (CH, CH-4-Ph1), 121.3 (CH, CH-5-Ph1), 124.1 (2CH, 2CH-3,5-Ph2), 126.0 (2CH, 2CH-2,6-Ph2), 133.6 (C, C-1-Ph2), 135.2 (=CH), 142.7 (C, C-1-Ph1), 145.6 (C, $\mathrm{C}-4-\mathrm{Ph} 2), 146.0$ (C, C-2-Ph1). Elemental analysis calcd (\%) for $\mathrm{C}_{14} \mathrm{H}_{13} \mathrm{~N}_{3} \mathrm{O}_{3}$ : C 61.99, $\mathrm{H} 4.83$, N 15.49; found: C 62.23, H 4.97, N 15.72.

\subsubsection{1-(4-bromobenzylidene)-2-phenylhydrazine (1n)}

The general procedure was used with 2-(4-bromobenzylidene)malononitrile $3 \mathrm{c}(0.5 \mathrm{~g})$ and phenylhydrazine $4 \mathrm{~m}(0.21 \mathrm{~mL})$ to obtain pure compound $1 \mathrm{n}$ as a white solid with the same NMR spectra as previously described [17] (0.36 g, 61\% yield); mp (EtOH) $121-123{ }^{\circ} \mathrm{C}$ (lit. mp 116-117 ${ }^{\circ} \mathrm{C}$ ) [17]; $\mathrm{R}_{\mathrm{f}}$ (EtOAc:Cyclohexane 1:1) = 0.62. ${ }^{1} \mathrm{H}-\mathrm{NMR}\left(\mathrm{CDCl}_{3}, 500 \mathrm{MHz}\right) \delta$ ppm 6.88-6.91 (m, 1H, ArH), $7.11(\mathrm{dd}, J=9.0,1.0 \mathrm{~Hz}, 2 \mathrm{H}, 2 \mathrm{ArH}), 7.27-7.30(\mathrm{~m}, 2 \mathrm{H}, 2 \mathrm{ArH})$, 7.48-7.53 (m, 5H, 4ArH + NH), $7.61(\mathrm{~s}, 1 \mathrm{H},=\mathrm{CH}) .{ }^{13} \mathrm{C}-\mathrm{NMR}\left(\mathrm{CDCl}_{3}, 125 \mathrm{MHz}\right) \delta \mathrm{ppm} 112.9$ (2CH, 2CH-3,5-Ph1), 120.5 (CH, CH-4-Ph1), 122.3 (C, C-4-Ph2), 127.7 (2CH, 2CH-2,6-Ph2), 129.5 (2CH, 2CH-2,6-Ph1), 131.9 (2CH, 2CH-3,5-Ph2), 134.4 (C, C-1-Ph2), 135.9 (=CH), 144.5 (C, C-1-Ph1). Elemental analysis calcd (\%) for $\mathrm{C}_{13} \mathrm{H}_{11} \mathrm{BrN}_{2}$ : C 56.75, $\mathrm{H} 4.03, \mathrm{~N} 10.18$; found: C 56.93, H 4.34, N 10.33.

\subsubsection{1-(4-bromobenzylidene)-2-(3,4-dimethylphenyl)hydrazine (1o)}

The general procedure was used with 2-(4-bromobenzylidene)malononitrile $3 \mathrm{c}(0.5 \mathrm{~g})$ and 3,4-dimethylphenylhydrazine $4 \mathbf{n}(0.29 \mathrm{~g})$ to obtain pure compound 10 as a white solid $(0.45 \mathrm{~g}, 69 \%$ yield $) ; \mathrm{mp}(\mathrm{EtOH}) 141-143{ }^{\circ} \mathrm{C} ; \mathrm{R}_{\mathrm{f}}($ EtOAc:Cyclohexane $1: 1)=0.59 .{ }^{1} \mathrm{H}-\mathrm{NMR}$ $\left(\mathrm{CDCl}_{3}, 500 \mathrm{MHz}\right) \delta$ ppm $2.20\left(\mathrm{~s}, 3 \mathrm{H}, \mathrm{CH}_{3}\right), 2.26\left(\mathrm{~s}, 3 \mathrm{H}, \mathrm{CH}_{3}\right), 6.84(\mathrm{~d}, J=7.5 \mathrm{~Hz}, 1 \mathrm{H}, \mathrm{ArH})$, $6.93(\mathrm{~s}, 1 \mathrm{H}, \mathrm{ArH}), 7.03(\mathrm{~d}, J=8.5 \mathrm{~Hz}, 1 \mathrm{H}, \mathrm{ArH}), 7.46-7.54(\mathrm{~m}, 4 \mathrm{H}, 4 \mathrm{ArH}), 7.58(\mathrm{br} \mathrm{s}, 2 \mathrm{H}, \mathrm{NH}+$ $=\mathrm{CH}) .{ }^{13} \mathrm{C}-\mathrm{NMR}\left(\mathrm{CDCl}_{3}, 125 \mathrm{MHz}\right) \delta \mathrm{ppm} 19.1\left(\mathrm{CH}_{3}\right), 20.2\left(\mathrm{CH}_{3}\right), 110.4(\mathrm{CH}, \mathrm{CH}-5-\mathrm{Ph} 1)$, 114.4 (CH, CH-2-Ph1), 122.1 (C, C-4-Ph2), 127.6 (2CH, 2CH-2,6-Ph2), 128.6 (C, C-3-Ph1), 130.5 (CH, CH-6-Ph1), 131.9 (2CH, 2CH-3,5-Ph2), 134.6 (C, C-1-Ph2), 135.3 (=CH), 137.7 (C, 
C-4-Ph1), 142.6 (C, C-1-Ph1). Elemental analysis calcd (\%) for $\mathrm{C}_{15} \mathrm{H}_{15} \mathrm{BrN}_{2}$ : C 59.42, H 4.99, N 9.24; found: C 59.65, H 5.07, N 9.50.

\subsection{X-ray Crystallography}

X-ray diffraction measurements for $1 \mathbf{e}$ and $\mathbf{1} \mathbf{i}$ were carried out with a Rigaku Oxford Diffraction XCALIBUR E CCD diffractometer (Rigaku Europe SE, Frankfurt, Germany) equipped with graphite-monochromated $\mathrm{MoK} \alpha$ radiation. The unit cell determination and data integration were carried out using the CrysAlis package of Oxford Diffraction (Rigaku Europe SE, Frankfurt, Germany) [18]. The structures were solved by intrinsic phasing using Olex2 [19] software with the SHELXT [20] structure solution program and refined by full-matrix least-squares on $F^{2}$ with SHELXL-2015 [20], using an anisotropic model for non-hydrogen atoms. All $\mathrm{H}$ atoms attached to carbon were introduced in idealized positions $\left(\mathrm{d}_{\mathrm{CH}}=0.96 \AA\right)$ using the riding model, with their isotropic displacement parameters fixed at $120 \%$ of their riding atom. The positions of $\mathrm{H}$ atoms for $\mathrm{NH}$ groups were determined from Fourier synthesis maps and verified through the hydrogen bonds parameters. Table S1 provides a summary of the crystallographic data together with refinement details for compounds. The geometric parameters are summarized in Table S2. The supplementary crystallographic data can be obtained free of charge via www.ccdc.cam.ac.uk/conts/retrieving.html (accessed on 19 July 2021) (or from the Cambridge Crystallographic Data Centre, 12 Union Road, Cambridge CB2 1EZ, UK; fax: $(+44)$ 1223-336-033; or deposit@ccdc.ca.ac.uk).

\subsection{MIC 99 Determination Assays}

$\mathrm{MIC}_{99}$ determination against Candida spp. was performed according to the standard culture microdilution method from the Clinical and Laboratory Standard Institute (CLSI). Inocula from Candida spp. strains were obtained from fungal cultures in Sabouraud dextrose agar (SDA) at $37^{\circ} \mathrm{C}$ for $24 \mathrm{~h}$. The initial concentration of Candida spp. strains was $1-5 \times 10^{6} \mathrm{CFU} / \mathrm{mL}$. The inocula were adjusted in order to obtain an optical density of 0.5 in the McFarland scale using sterile $\mathrm{mQ}$ water. Cells were suspended in RPMI 1640 medium to obtain a final concentration of $5 \times 10^{3} \mathrm{CFU} / \mathrm{mL}$. The evaluation of the antifungal activity of hydrazone derivatives was performed against C. albicans, C. dubliniensis, C. glabrata, C. parapsilosis and C. tropicalis cultured in 96-well microplates at different concentrations $(0.06 \mu \mathrm{g} / \mathrm{mL}$ to $32 \mu \mathrm{g} / \mathrm{mL})$ at $37^{\circ} \mathrm{C}$ for $24 \mathrm{~h}$. Growth and sterility controls were also used. On the other hand, a positive control was also realized with fluconazole $(0.5 \mu \mathrm{g} / \mathrm{mL}$ and $0.06 \mu \mathrm{g} / \mathrm{mL}$ ). Fungal growth was determined in colorimetric assays (Alamarblue ${ }^{\mathrm{TM}}$, Thermo Fisher Scientific Inc., Illkirch, France). Minimum IC (MIC 99 ) was defined as the lowest concentration of hydrazone derivative that produces a reduction of $99 \%$ of the yeast growth compared to controls (in the absence of compound).

\subsection{Cell Viability Assay}

Human HEK293 cells (Human Embryonic Kidney 293) were purchased from the American Type Culture Collection (ATCC, Manassas, VA, USA) and were grown in triple flask to $95 \%$ confluence and resuspended for dispensing at $1.25 \times 10^{5}$ cells $/ \mathrm{mL}$ of DMEM, $10 \%$ FBS/Pen/Strep/L-glutamine. HEK293 cells were plated in 96-well microplates (5000 cells per well in $40 \mu \mathrm{L}$ media (DMEM/10\%FBS/Pen/Strep/L-glutamine)) before incubation in standard conditions $\left(5 \% \mathrm{CO}_{2} ; 95 \%\right.$ humidity, $\left.37^{\circ} \mathrm{C}\right)$ for $24 \mathrm{~h}$.

Subsequently, cells were overlaid with RPMI medium containing different concentrations of drugs $(0.06 \mu \mathrm{g} / \mathrm{mL}$ to $32 \mu \mathrm{g} / \mathrm{mL})$, and cell viability was determined using MTT reagent as per manufacturer's recommendations.

\subsection{Cancer Cell Proliferation Assay}

Compounds $\mathbf{1 c}, \mathbf{1 d}, \mathbf{1 i}, \mathbf{1 k}$ and $\mathbf{1 l}$ were tested against a panel of 60 human cancer cell lines at the National Cancer Institute (NCI), Germantown, MD, USA [21]. The cytotoxicity 
studies were conducted using a 48-h exposure protocol using the sulforhodamine B (SRB) assay [22].

\section{Conclusions}

An attempt to isolate pyrazoles derivatives, by reacting benzylidenemalononitriles with hydrazines in refluxing ethanol, did not provide the target heterocyclic systems, as expected and as previously reported, but instead hydrazones whose structure was secured by both chemical evidence and X-ray studies. Indeed, the direct reaction of 3,4,5trimethoxybenzaldehyde with 2,4-dichlorophenylhydrazine furnished the same hydrazone as that obtained from benzylidenemalononitrile with hydrazine. This study identified five hydrazones as promising antifungal agents ( $\mathrm{MIC}_{99}$ values ranging from 16 to $32 \mu \mathrm{g} / \mathrm{mL}$ ) against Candida spp. These compounds showed a $\mathrm{CC}_{50}$ (concentration at $50 \%$ cytotoxicity) value against HEK293 cells at $>32 \mu \mathrm{g} / \mathrm{mL}$ and against NCI-60 cancer cell lines panel at $>10 \mu \mathrm{M}$, demonstrating selective antifungal activity over cytotoxicity. Compared to known acylhydrazones and hydrazones previously reported in the literature, a selection of which is available in Figure 1, the newly synthesized hydrazones are positioned as very promising experimental molecules with antifungal activity on Candida spp.

Supplementary Materials: The following are available online: full description of the crystal structure of $1 \mathrm{e}$ and $\mathbf{1 i}$, and one-dose full graphs obtained for active molecules $1 \mathrm{c}, 1 \mathrm{~d}, 1 \mathrm{i}, 1 \mathrm{k}$ and 11 on NCI-60 cancer cell lines panel associated with this article.

Author Contributions: Conceptualization, A.G. and E.B.; methodology, G.N., L.K. and F.D.; software, S.S.; validation, A.G. and S.S.; formal analysis, G.N. and L.K.; investigation, G.N., L.K., F.D., S.S. and A.G.; resources, A.G., E.B. and B.S.; data curation, A.G., E.B. and F.D.; writing-original draft preparation, A.G.; writing - review and editing, A.G., E.B. and F.D.; visualization, A.G.; supervision, A.G.; E.B. and F.D.; project administration, A.G., E.B. and F.D.; funding acquisition, A.G. All authors have read and agreed to the published version of the manuscript.

Funding: The authors gratefully acknowledge the financial support received from the Executive Unit for Financing Higher Education, Research, Development and Innovation (UEFISCDI), Bucharest, Romania, grant number PN-III-P4-ID-PCE-2020-0818, acronym: REPAIR. The APC was also funded by UEFISCDI.

Institutional Review Board Statement: Not applicable.

Informed Consent Statement: Not applicable.

Data Availability Statement: The data presented in this study are available on request from the corresponding author. Supplementary Materials include X-Ray crystallography and NCI-60 data.

Acknowledgments: The authors also thank the CERNESIM Center within the Interdisciplinary Research Institute at "Alexandru Ioan Cuza" University of Iași, Romania for the infrastructure used in recording NMR experiments. The authors gratefully acknowledge the National Cancer Institute (NCI) for the biological evaluation of compounds $1 \mathrm{c}, 1 \mathrm{~d}, 1 \mathbf{1}, \mathbf{1 k}$ and 11 on their 60 -cell panel. The testing was performed by the Developmental Therapeutics Program, Division of Cancer Treatment and Diagnosis (the URL to the Program's website: http:/ / dtp.cancer.gov, accessed on 21 June 2021).

Conflicts of Interest: The authors declare no conflict of interest.

Sample Availability: Samples of the compounds 1a-o are available from the authors.

\section{References}

1. WHO. First Meeting of the WHO Antifungal Expert Group on Identifying Priority Fungal Pathogens. Available online: https: //www.who.int/publications/i/item/9789240006355 (accessed on 19 July 2021).

2. Pappas, P.G.; Kauffman, C.A.; Andes, D.R.; Clancy, C.J;; Marr, K.A.; Ostrosky-Zeichner, L.; Reboli, A.C.; Schuster, M.G.; Vazquez, J.A.; Walsh, T.J.; et al. Clinical Practice Guideline for the Management of Candidiasis: 2016 Update by the Infectious Diseases Society of America. Clin. Infect. Dis. 2016, 62, e1-e50. [CrossRef] [PubMed] 
3. Ullmann, A.J.; Akova, M.; Herbrecht, R.; Viscoli, C.; Arendrup, M.C.; Arikan-Akdagli, S.; Bassetti, M.; Bille, J.; Calandra, T.; Castagnola, E.; et al. ESCMID* guideline for the diagnosis and management of Candida diseases 2012: Adults with haematological malignancies and after haematopoietic stem cell transplantation (HCT). Clin. Microbiol. Infect. 2012, $18,53-67$. [CrossRef] [PubMed]

4. Hope, W.W.; Castagnola, E.; Groll, A.H.; Roilides, E.; Akova, M.; Arendrup, M.C.; Arikan-Akdagli, S.; Bassetti, M.; Bille, J.; Cornely, O.A.; et al. ESCMID* guideline for the diagnosis and management of Candida diseases 2012: Prevention and management of invasive infections in neonates and children caused by Candida spp. Clin. Microbiol. Infect. 2012, 18, 38-52. [CrossRef] [PubMed]

5. Cornely, O.A.; Bassetti, M.; Calandra, T.; Garbino, J.; Kullberg, B.J.; Lortholary, O.; Meersseman, W.; Akova, M.; Arendrup, M.C.; Arikan-Akdagli, S.; et al. ESCMID* guideline for the diagnosis and management of Candida diseases 2012: Non-neutropenic adult patients. Clin. Microbiol. Infect. 2012, 18, 19-37. [CrossRef] [PubMed]

6. Datry, A.; Bart-Delabesse, E. Caspofungin: Mode of action and therapeutic applications. Rev. Med. Interne 2006, 27, 32-39. [CrossRef] [PubMed]

7. Reis, D.C.; Despaigne, A.A.R.; Da Silva, J.G.; Silva, N.F.; Vilela, C.F.; Mendes, I.C.; Takahashi, J.A.; Beraldo, H. Structural Studies and Investigation on the Activity of Imidazole-Derived Thiosemicarbazones and Hydrazones against Crop-Related Fungi. Molecules 2013, 18, 12645-12662. [CrossRef] [PubMed]

8. Neumann, D.M.; Cammarata, A.; Backes, G.; Palmer, G.E.; Jursic, B.S. Synthesis and antifungal activity of substituted 2,4,6pyrimidinetrione carbaldehyde hydrazones. Bioorg. Med. Chem. 2014, 22, 813-826. [CrossRef] [PubMed]

9. Chimenti, F.; Bizzarri, B.; Bolasco, A.; Secci, D.; Chimenti, P.; Granese, A.; Carradori, S.; D’ Ascenzio, M.; Lilli, D.; Rivanera, D. Synthesis and biological evaluation of novel 2,4-disubstituted-1,3-thiazoles as anti-Candida spp. Agents. Eur. J. Med. Chem. 2011, 46, 378-382. [CrossRef] [PubMed]

10. Ortiz, S.; Nelson, R.; Kesternich, V.; Perez-Fehrmann, M.; Christen, P.; Marcourt, L. Synthesis and Antifungal Activity of Diaryl Hydrazones from 2,4-Dinitrophenylhydrazine. J. Chil. Chem. Soc. 2016, 61, 3081-3084. [CrossRef]

11. Gouhar, R.S.; Fathalla, O.A.; Abd El-Karim, S.S. Synthesis and anticancer screening of some novel substituted pyrazole derivatives. Der Pharma Chem. 2013, 5, 225-233.

12. Kulkarni, A.; Quang, P.; Curry, V.; Keyes, R.; Zhou, W.; Cho, H.; Baffoe, J.; Török, B.; Stieglitz, K. 1,3-disubstituted-4-aminopyrazolo [3, 4-d] pyrimidines, a new class of potent inhibitors for phospholipase D. Chem. Biol. Drug Des. 2014, 84, 270-281. [CrossRef]

13. Attar, S.R.; Shinde, B.; Kamble, S.B. Enhanced catalytic activity of bio-fabricated ZnO NPs prepared by ultrasound-assisted route for the synthesis of tetraketone and benzylidenemalonitrile in hydrotropic aqueous medium. Res. Chem. Intermed. 2020, 46, 4723-4748. [CrossRef]

14. Wang, Z.; Yuan, X.; Cheng, Q.; Zhang, T.; Luo, J. An efficient and recyclable acid-base bifunctional core-shell nano-catalyst for the one-pot deacetalization-Knoevenagel tandem reaction. New J. Chem. 2018, 42, 11610-11615.

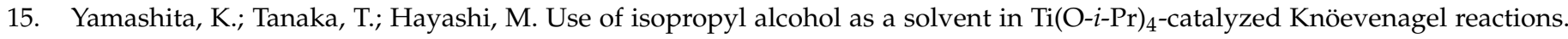
Tetrahedron 2005, 61, 7981-7985. [CrossRef]

16. Khan, M.; Ahad, G.; Manaf, A.; Naz, R.; Hussain, S.R.; Deeba, F.; Shah, S.; Khan, A.; Ali, M.; Zaman, K.; et al. Synthesis, in vitro urease inhibitory activity, and molecular docking studies of (perfluorophenyl)hydrazone derivatives. Med. Chem. Res. 2019, 28, 873-883. [CrossRef]

17. Buzykin, B.I. Synthesis and spectral characteristics of 1,4-diaryl-2-arylidenebenzhydrazidines. Izv. Akad. Nauk. SSSR Seriya Khimicheskaya 1983, 7, 1588-1593. [CrossRef]

18. Rigaku Oxford Diffraction. CrysAlisPro Software System; Version 1.171.38.46; Rigaku Corporation: Oxford, UK, 2015.

19. Dolomanov, O.V.; Bourhis, L.J.; Gildea, R.J.; Howard, J.A.K.; Puschmann, H. OLEX2: A complete structure solution, refinement and analysis program. J. Appl. Crystallogr. 2009, 42, 339-341. [CrossRef]

20. Sheldrick, G. SHELXT-Integrated space-group and crystal-structure determination. Acta Cryst. A 2015, 71, 3-8. [CrossRef] [PubMed]

21. Boyd, R.B. The NCI In Vitro Anticancer Drug Discovery Screen; Humana Press Inc.: Totowa, NJ, USA, 1997 ; pp. $23-42$.

22. Shoemaker, R.H. The NCI60 human tumour cell line anticancer drug screen. Nat. Rev. 2006, 6, 813-823. [CrossRef] [PubMed] 